\title{
A review of the performance of woody and herbaceous ornamental plants for phytoremediation in urban areas
}

\section{Maurizio Capuana}

\begin{abstract}
Urban and periurban areas are often contaminated by several pollutants. Phytoremediation is considered to be an effective and eco-friendly strategy for the restoration of these contaminated lands. For this purpose, the exploitation of ornamental plants could be an additional option, due to their positive impact on the landscape. In this paper, we reviewed a selection of species which have been proposed for utilization in phytoremediation. Several tree species have been introduced in the past into urban environments for parks, gardens and avenues, with a selection studied for their capacity to absorb, tolerate, and translocate contaminants. Shrubby and herbaceous species are also commonly exploited for their ornamental features and are now studied for phytoremediation purposes. The responses of several effective species to the presence of heavy metals or dangerous organic compounds in the growth substrate are examined in this paper.
\end{abstract}

\section{Keywords: Environment, Heavy Metals, Landscape, Organics, Pollution}

\section{Introduction}

Environmental pollution is an increasing global problem. Contaminants vary depending upon their source and the type of ecosystem involved. Urban areas can be affected by several organic and inorganic contaminants, which negatively impact soils, water and the atmosphere (Biasioli et al. 2006). The study of the effect of contamination by pollutants on these urban environments and potential solutions to the problems associated with soil contamination and rehabilitation dates to the last few decades (Tiller 1992).

Urban and periurban soils are often polluted as consequence of human activities. Brownfield sites, mainly located in periurban sites, reflect industrial heritage and are probably the most common scenarios where urban and periurban contaminated soils are found (Sleegers 2010). In general, heavy metals are the major contaminants:

$\square$ Institute of Biosciences and Bioresources, National Research Council, v. Madonna del Piano 10, I-50019 Sesto Fiorentino, FI (Italy)

\section{@ Maurizio Capuana}

(maurizio.capuana@ibbr.cnr.it)

Received: Sep 18, 2019 - Accepted: Feb 07, 2020

Citation: Capuana M (2020). A review of the performance of woody and herbaceous ornamental plants for phytoremediation in urban areas. iForest 13: 139-151. - doi: 10.3832/ifor3242-013 [online 2020-04-14]

Communicated by: Werther Guidi Nissim lead is commonly found near roads and associated with zinc and cadmium (Garcia \& Millan 1998); excessive copper is frequently detected in soils used for a long period as agricultural land, especially vineyards (Bretzel \& Calderisi 2006), and chromium is a residual of some industrial activities (Zayad \& Terry 2003). Organic pollutants can also injure urban soils by direct contamination, or after initial emission into the atmosphere followed by transport in both gaseous and particulate forms, and subsequent accumulation in soils after dry and wet atmospheric deposition (Cachada et al. 2012). Urban soils may also be very different to more natural soils, due to lower organic fraction, water drainage and aeration, different $\mathrm{pH}$ value, microorganism content and the presence of anthropic material. These features can change the performance of these soils with respect to pollutants (Tiller 1992, Schleu et al. 1998). As stated by Cunningham \& Berti (1993) "new technologies are needed to address numerous contaminants, especially those that are neither volatile nor mobile in soil solution". Plants have been proposed to mitigate the dangerous effects of pollutants, with phytoremediation recognized as a promising technology for the recovery of contaminated environments (Salt et al. 1995). Phytoremediation could be successfully exploited in urban territories; in these contexts, many herbaceous and some woody species (including forest species) are suitable for planting because of their ornamental features and adaptability to inhabited areas. Furthermore, plants are useful sensors to identify environmental contamination and potential exposures to pollutants (Henry et al. 2013). In fact, some of these species show the capacity to absorb, hold or translocate specific contaminants; moreover, these ornamentals pose little threat to food chain contamination, and can be appreciated by the resident populations for their positive impact on landscape.

In the more circumscribed field of flowerbeds and urban green plantations, special mixtures of topsoil are commonly used and rules have to be followed with regards to the presence of contaminants (Huinink 1998). Risks are higher in allotments, since contaminants could be transferred to the food chain (Scheyer 2000, Khalid et al. 2017). Attention has to be paid to parks, playgrounds, kindergartens and urban areas where people come into close contact with soil (Abrahams 2002, Chiesura 2004, De Miguel et al. 2006, Lee et al. 2006, Ljung et al. 2006a, Ljung et al. 2006b). In these areas, selected ornamental plants may play an important role in reducing the presence of pollutants, while at the same time giving a pleasant temporary decoration. Botanists have elaborated several definitions of ornamental plants; these can be defined as plants that have highly ornamental features such as ornamental flowers, fruits or foliage (Li \& Zhou 2005). Nevertheless, we must also consider that the ornamental value of a plant may vary according to the different tastes and traditions of each country.

The focus of our attention is the "original" soils, and the present article is aimed primarily at suburban areas, which can be even heavily contaminated, due to their past uses. If the plants chosen to be used in remediation are tree species, several selection criteria have to be taken into account (Conway \& Vander Vecht 2015), including problems linked to climate change 


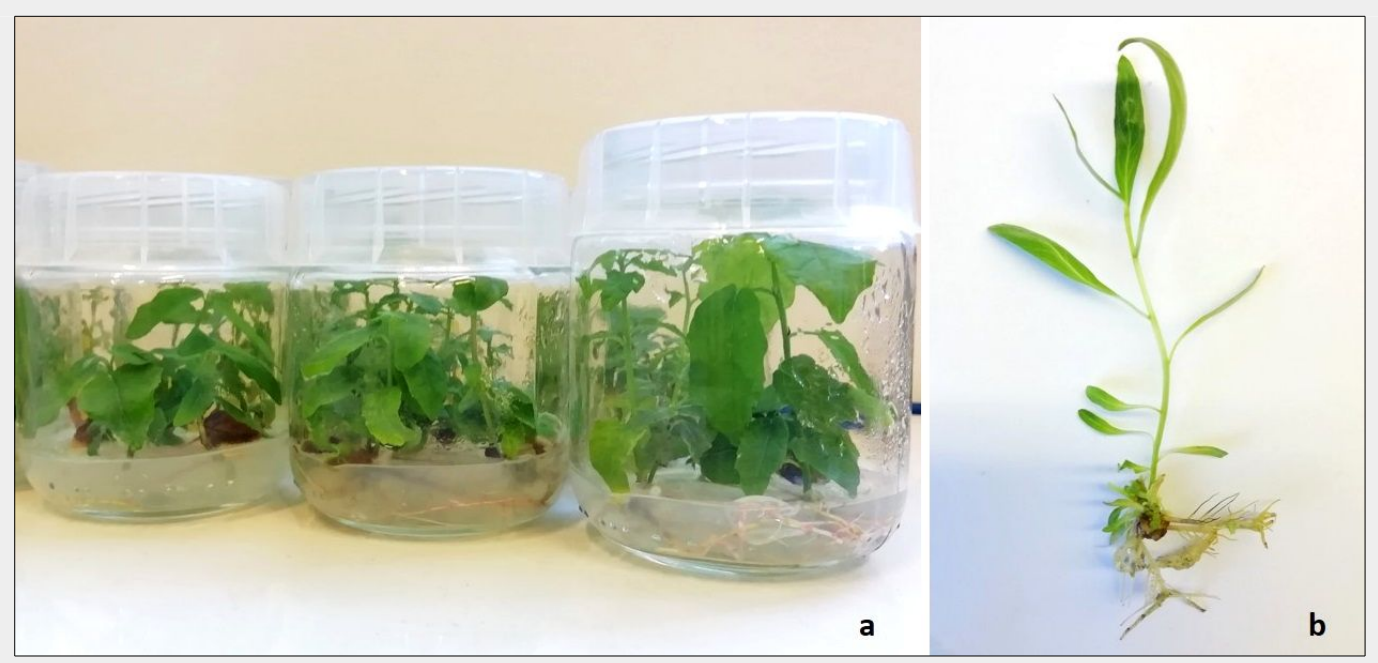

Fig. 1 - In vitro culture for the rapid mass propagation of plants to be exploited in phytoremediation: (a) multiclonal culture of Populus alba; (b) in vitrorooted plantlet of Salix alba.

(Roloff et al. 2009, Killi et al. 2018) and the preferences expressed by the resident populations (these inclinations are generally for plantations with high level of biodiversity - Carrus et al. 2015). Also, it is always advisable to consider all of the actions related to the sustainability of plantations (Ferrini \& Fini 2011) and the analysis of costs for their periodic removal and disposal (Berndes et al. 2004, Lewandowski et al. 2006, Compernolle et al. 2012, Saxena et al. 2019, Wan et al. 2016).

In this context, we might also consider the possible use of tree planting for shortrotation coppicing, by which a profitable recovery of the used plants can be performed. For instance, willows may be exploited for this purpose, since these species display high ornamental value and are suitable for bioenergy production combined with potential for phytoremediation (Guidi et al. 2013, Guidi Nissim et al. 2014b). Therefore, the choice of species to be used for phytoremediation includes consideration of criteria such as respect for biodiversity, easy harvesting management, byproduct utilisation and possible economic returns.

After their use for soil remediation, all plants (woody and herbaceous) must be harvested and treated, since the content of pollutants is an important concern. Several solutions are available for this purpose, including compacting, composting, biogas production and pyrolysis (Blaylock \& Huang 2000, Nanda Kumar et al. 1995, Garbisu \& Alkorta 2001). The easiest procedure is incineration of biomass, with recovery of residual heavy metals. When ornamental flowers are used, cut flowers with limited contaminants content can be eventually sold.

An overview is provided of the most effective woody and herbaceous plants (tree species, shrubs and herbaceous flowers) for the remediation of urban and suburban areas, through analysis of recent literature illustrating how these species react when facing either inorganic (heavy metals) or organic contaminants. This review is specifically addressed to a selection of species suitable for exploitation in urban environments, due to their adaptability, ornamental characteristics and appreciation by resident populations; the proposed selection, albeit large, is mainly focused on the species best suited to European and American environments.
Several tree species have been successfully used in urban parks, gardens and avenues; for instance, in Europe pines, cypresses, poplars, willows, birches, sycamores and lindens are widely planted (Miller et al. 2015). Numerous recent studies demonstrated that some tree species have a good attitude to tolerate, absorb and remove specific contaminants from the soil (reviewed by Mahar et al. 2016, Pajević et al. 2016). Trees can enhance the aesthetic quality of urban landscape (Chen et al. 2009), simultaneously providing other functions, such as improved air quality (Mukherjee \& Agrawal 2018), reduction of noise pollution (Pathak et al. 2011), mitigation of waterlogging (Livesley et al. 2016) and reducing heat island effects (Scholz et al. 2018 - Fig. 1, Fig. 2).

A great variety of herbaceous and shrubby species have been analysed for phytoremediation purposes (reviewed by Liu et al. 2018 - Fig. 3), but many still remain to be studied. Furthermore, plants' association, with its huge possibilities of combinations, offers interesting perspectives and is therefore discussed.

The choice of ornamental woody and herbaceous plants for urban (and periur-
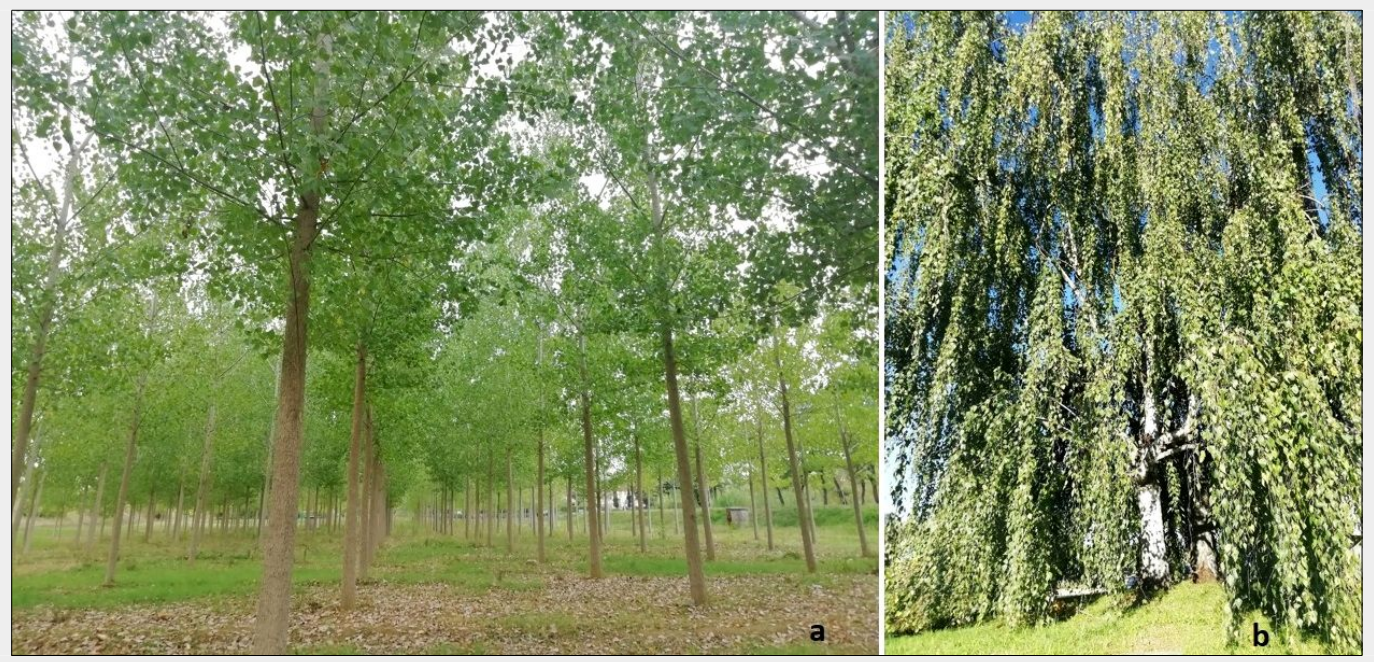

Fig. 2 - Woody species for phytoremediation: (a) a poplar plantation in an urban site (outskirts of Florence); (b) Betula pendula. 
Fig. 3 - Two widespread ornamental species studied and proposed for phytoremediation purposes: (a) Chrysanthemum; (b) Nerium oleander.
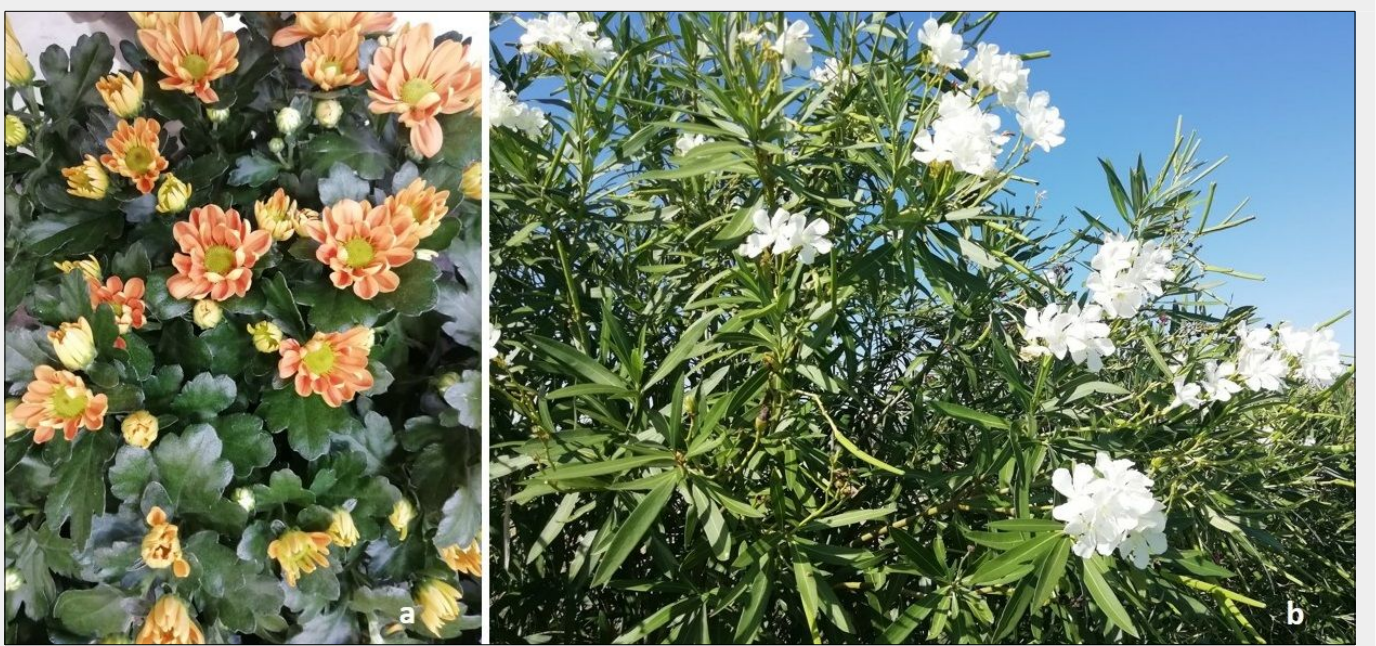

ban) environments should also take into account some factors. In these sites (often smaller areas compared to the countryside), the problem of the scattering of leaves could be more relevant; especially when using trees, and for species that translocate pollutants to the leaves, leaves should be periodically collected and treated. Moreover, due to the greater anthropic presence in urban site and transport constraints, it is probably opportune to choose species that have less maintenance needs and leaves which are easier to collect at the end of the leaf life-cycle.

\section{Heavy metals}

Pollution from industrial emissions, effluents and solid discharges are the main source of an abnormal high presence of heavy metals in soils. In general, numerous human activities result in the emission of these harmful pollutants that enter into the biosphere through wastes (emission, waste-water and waste solid), including municipal wastes in agriculture and excessive use of fertilizers. Several plant species have the capacity to absorb and translocate specific metals; a selection of woody and herbaceous species, which could be identified as "multipurpose species", are reviewed below, for their possible utilisation in metal remediation coupled to considerable ornamental features (Tab. 1, Tab. 2).

\section{Woody species}

Among tree species traditionally used in urban and periurban plantations, a limited number showed suitability for phytoremediation purposes. Analysis of the recent literature indicates that the most promising are some species of the Salicaceae family (Salix spp., Populus spp.), but some others also show significant pollution resistance traits, such as Ailanthus altissima, Robinia pseudoacacia, Betula pendula, Carpinus betulus, Ginkgo biloba and Platanus hispanica (Dadea et al. 2017). Several tree species (mainly willows and poplars) are not hyperaccumulators, but do exhibit traits of high interest, such as fast growth and high pro- duction of biomass, easy propagation, a deep root system and the capacity to uptake and translocate a significant amount of metal contaminants in the soil to the shoots (Vassilev et al. 2004, Guerra et al. 2011). Poplars in particular, display a number of different characteristics useful towards environmental protection, which include phytoremediation, especially in combination with short rotation forestry and landscape restoration (Facciotto et al. 2014). Woody species may also be utilised for the plantation of green belts around contaminated lands. Eucalypts, willows and poplars are all fast-growing trees with short rotation coppice systems that could be successfully utilised for this purpose (Pulford \& Watson 2003). This phytoremediation would have to be undertaken in consideration of the need to harmonize these choices with the landscape character, as generally requested by the resident populations (Boll et al. 2014).

The effect of lead $(\mathrm{Pb})$ has been assessed in one-year-old potted seedlings of Cappadocian maple (Acer cappadocicum), European ash (Fraxinus excelsior) and Oriental aborvitae (Platycladus orientalis). Increasing $\mathrm{Pb}$ application in the soil (from 100 to $500 \mathrm{mg} \mathrm{kg}^{-1}$ ) did not affect the dry weight of roots of all species, while a gradual decrease was detected in leaves and shoots, with the highest inhibition in P. orientalis. This species, however, showed the highest translocation factor values, tolerance index and bioconcentration factor, indicating a possible use of this conifer species for remediation of $\mathrm{Pb}$-polluted soils (Abbasi et al. 2017). The bioconcentration factor (BF) is defined as the ratio of metal(loid) concentration in aerial biomass to that in soil, and the translocation factor (TF) the ratio of metal(loid) concentration in shoots to that in roots, both factors taking values $>1$ in accumulators and $<1$ in excluders; the tolerance index (TI) is the percent of the organ's growth of the treated plant compared to the growth of the control plant (McGrath \& Zhao 2003, Turner et al. 1991). Three leguminous woody species, Mimosa caesalpiniaefolia, Erythrina speciosa and Schizolobium parahyba, were tested in a lead-contaminated area. While $M$. caesalpiniaefolia did not show symptoms of $\mathrm{Pb}$ toxicity, the other two species exhibited reduced shoot biomass yield, leaf area and height. The increase of $\mathrm{Pb}$ concentrations in soil led to augmented $\mathrm{Pb}$ concentration in shoots and roots, but most of the $\mathrm{Pb}$ accumulated in the roots, and only a small fraction was translocated to the aboveground parts of the plant. Mimosa showed the highest $\mathrm{Pb}$ tolerance and phytostabilisation potential in lead-contaminated soils (Ribeiro De Souza et al. 2012).

In a study to identify candidate species among fast-growing trees for remediating $\mathrm{Pb}$-contaminated soils (Yongpisanphop et al. 2017), hydroponic cultures of cuttings from Acacia mangium, Azadirachta indica, Eucalyptus camaldulensis, and Senna siamea, were tested in increasing $\mathrm{Pb}$ concentrations. All species showed high $\mathrm{Pb}$ tolerance (over $78 \%$ ) but low TF (<1) for all treatments (10, 30, and $50 \mathrm{mg} \mathrm{L}^{-1}$ ). Based on these indices, $A$. mangium and E. camaldulensis were found to be good candidate species for $\mathrm{Pb}$ remediation (Yongpisanphop et al. 2017).

Willow (Salix nigra) showed a moderate tolerance to silver $(\mathrm{Ag})$ in a hydroponic experiment with increasing $\mathrm{AgNO}_{3}$ concentrations, observing a significant reduction of biomass production with $\mathrm{AgNO}_{3} 0.027 \mu \mathrm{M}$, but also adaptation signals over a longer timeline (Guidi Nissim et al. 2014a).

Eastern cottonwood (Populus deltoides) was evaluated for arsenic (As) tolerance and phytostabilization potential, by exposure to various As levels in soil (control, 5 , 10,15 , and $20 \mathrm{mg} \mathrm{kg}^{-1}$ ) in a 9-month pot experiment. Plant height stress tolerance index ( $\mathrm{TI})$ significantly decreased with increasing As levels, while indices related to root length and dry matter were not affected. TF and BF were less than 1.0, but root and shoot As content significantly increased with increasing As concentrations (Hussain et al. 2017). The effect of high copper $(\mathrm{Cu})$ concentrations was investigated on poplar woody cuttings (Populus $\times$ euramericana, clone "Adda"), finding that in- 
Tab. 1 - Ornamental plants for the phytoremediation of heavy metal: trees and shrubs. (A): accumulation; $(\mathrm{T})$ : translocation.

\begin{tabular}{|c|c|c|c|c|}
\hline Group & Species & Pollutants & $\mathrm{A} / \mathrm{T}$ & References \\
\hline \multirow{29}{*}{$\stackrel{\varrho}{\stackrel{\Perp}{\Perp}}$} & Acacia mangium & $\mathrm{Pb}$ & $A$ & Yongpisanphop et al. 2017 \\
\hline & Acer cappadocicum & $\mathrm{Pb}$ & A & Abbasi et al. 2017 \\
\hline & Azadirachta indica & $\mathrm{Pb}$ & A & Yongpisanphop et al. 2017 \\
\hline & Betula pendula & $\mathrm{Zn}$ & $\mathrm{A}, \mathrm{T}$ (partial) & Rosselli et al. 2003 \\
\hline & Cinnamomum camphora & $\mathrm{Zn}$ & $\mathrm{A}, \mathrm{T}$ & Zeng et al. 2018 \\
\hline & \multirow{2}{*}{$\begin{array}{l}\text { Eucalyptus } \\
\text { camaldulensis }\end{array}$} & $\mathrm{Pb}$ & A & \multirow{2}{*}{$\begin{array}{l}\text { Yongpisanphop et al. 2017, } \\
\text { Motesharezadeh et al. } 2017\end{array}$} \\
\hline & & $\mathrm{Cd}$ & $\mathrm{T}$ & \\
\hline & Fraxinus excelsior & $\mathrm{Pb}$ & A & Abbasi et al. 2017 \\
\hline & Mimosa cesalpiniaefolia & $\mathrm{Pb}$ & $A$ & Abbasi et al. 2017 \\
\hline & Platycladus orientalis & $\mathrm{Pb}$ & $\mathrm{T}$ & Abbasi et al. 2017 \\
\hline & Populus alba & $\mathrm{Cd}, \mathrm{Pb}$ & $A$ & $\begin{array}{l}\text { Houda et al. 2016, Zacchini } \\
\text { et al. } 2009\end{array}$ \\
\hline & \multirow[t]{2}{*}{ Populus deltoides } & As & $A$ & Hussain et al. 2017 \\
\hline & & $\mathrm{Cd}$ & A & Zacchini et al. 2009 \\
\hline & Populus nigra & $\mathrm{Cd}$ & $A$ & Zacchini et al. 2009 \\
\hline & Populus trichocarpa & $\mathrm{Cd}$ & $A$ & Zacchini et al. 2009 \\
\hline & Populus $\times$ canadensis & $\mathrm{Cd}$ & A & Zacchini et al. 2009 \\
\hline & \multirow[t]{3}{*}{ Populus $\times$ euramericana } & $\mathrm{Cu}$ & A & Borghi et al. 2007 \\
\hline & & $\mathrm{Zn}$ & $\mathrm{T}$ (partial) & Di Baccio et al. 2003 \\
\hline & & $\mathrm{Cr}, \mathrm{Fe}$ & $\mathrm{T}$ (partial) & Giachetti \& Sebastiani 2006 \\
\hline & Populus $\times$ generosa & $\mathrm{Cd}$ & $\mathrm{A}$ & Zacchini et al. 2009 \\
\hline & \multirow[t]{2}{*}{ Salix dasyclados } & $\mathrm{Cd}$ & $A$ & Landberg \& Greger 1994 \\
\hline & & $\mathrm{Zn}$ & $\mathrm{T}$ & Vyslouzilová et al. 2003 \\
\hline & Salix fragilis & $\mathrm{Cd}, \mathrm{Zn}$ & $T$ & Meers et al. 2007 \\
\hline & Salix miyabeana & Zn & $T$ & Desjardins et al. 2016 \\
\hline & Salix nigra & $\mathrm{Ag}$ & A & Guidi Nissim et al. 2014b \\
\hline & Salix schwerinii & $\mathrm{Cd}, \mathrm{Zn}$ & $\mathrm{T}$ & Meers et al. 2007 \\
\hline & \multirow[t]{2}{*}{ Salix viminalis } & Cd & A & Landberg \& Greger 1994 \\
\hline & & $\mathrm{Zn}$ & $T$ & Vyslouzilová et al. 2003 \\
\hline & Senna siamea & $\mathrm{Pb}$ & A & Yongpisanphop et al. 2017 \\
\hline \multirow{12}{*}{$\begin{array}{l}\frac{n}{2} \\
\frac{2}{n}\end{array}$} & Buddleja asiatica & $\mathrm{Pb}$ & $\mathrm{T}$ & Waranusantigul et al. 2008 \\
\hline & Buddleja paniculata & $\mathrm{Pb}$ & $\mathrm{T}$ & Waranusantigul et al. 2008 \\
\hline & Catharanthus roseus & $\mathrm{Ni}, \mathrm{Pb}$ & $A$ & Subhashini \& Swamy 2013 \\
\hline & Euonimus japonicus & Cd & A & Zeng et al. 2018 \\
\hline & Euphorbia milii & $\mathrm{Cr}$ & $\mathrm{T}$ & Ramana et al. 2015 \\
\hline & Ligustrum vicaryi & $\mathrm{Cd}$ & $A$ & Zeng et al. 2018 \\
\hline & Lonicera japonica & $\mathrm{Cd}$ & $\mathrm{T}$ & Liu et al. 2009 \\
\hline & Loropetalum chinense & $\mathrm{Cd}$ & $\mathrm{A}$ & Zeng et al. 2018 \\
\hline & \multirow[t]{2}{*}{ Osmanthus fragrans } & $\mathrm{Cd}$ & $A, T$ & $\begin{array}{l}\text { Zeng et al. 2018, Wu et al. } \\
2011\end{array}$ \\
\hline & & $\mathrm{Pb}$ & $T$ & Wu et al. 2011 \\
\hline & Rhapis excelsa & $\mathrm{Cd}$ & $A$ & Zhang et al. 2010 \\
\hline & Ricinus communis & $\mathrm{Ni}$ & $A$ & Adhikari \& Kumar 2012 \\
\hline
\end{tabular}

creasing levels of $\mathrm{Cu}$ up to $100 \mu \mathrm{M}$ resulted in a general reduction of plant growth and that the metal was mainly accumulated in the root system at all Cu levels (Borghi et al. 2007). Several poplar species (Populus alba, P. deltoides, P. nigra, $P$. trichocarpa, $P$. $\times$ generosa, $P \times$ canadensis) showed the capacity to accumulate cadmium (Cd), albeit with different effectiveness (Zacchini et al. 2009). Poplars also demonstrated phytoextraction capacity for zinc ( $Z n$ - Di Baccio et al. 2003).

Cadmium accumulation was also demonstrated in Cinnamomum camphora, that showed the maximum $\mathrm{Cd}$ content in stems and leaves (Zeng et al. 2018).

In a greenhouse experiment on ornamental plants, four shrubs (Osmanthus fra- grans, Ligustrum vicaryi, Loropetalum chinense var. rubrum, and Euonymus japonicus $\mathrm{cv}$. Aureo-mar) were tested in the presence of $\mathrm{Cd}$. The results showed that these species can grow normally at $\mathrm{Cd}$ soil concentrations lower than $24.6 \mathrm{mg} \mathrm{kg}^{-1}$. The metal accumulated principally in the roots, with the highest amount detected in Euomymus (Zeng et al. 2018).

Rhapis excelsa, Camellia polyodonta and C. gigantocarpa were tested for soil $\mathrm{Cd}$ absorption in a pot experiment with different Cd treatments (10, 25 and $50 \mathrm{mg} \mathrm{kg}^{-1}$ ). The three species never showed any toxic symptom and grew well at all Cd concentrations. Cadmium contents was higher in the roots than in the stems and leaves. At $50 \mathrm{mg} \mathrm{kg}^{-1} \mathrm{Cd}$ concentration, the $\mathrm{Cd}$ con- tent in the roots of Rhapis excelsa was the highest amongst all the tested species and 7.05 times higher than that at $10 \mathrm{mg} \mathrm{kg}^{-1} \mathrm{Cd}$ concentration (Zhang et al. 2010). Lonicera japonica plants exposed to $\mathrm{Cd}$ concentrations up to $50 \mathrm{mg} \mathrm{L}^{-1}$ did not show significant differences (compared to control) in height and dry biomass of leaves and roots. Tls were all above 0.8 and the high $\mathrm{BF}$ and TF justified the proposal to include the species in the list of potential Cd accumulators (Liu et al. 2009).

The ornamental shrub Euphorbia milii tolerated up to $75 \mathrm{mg}$ of applied $\mathrm{Cr}$ per $\mathrm{Kg}$ soil, and was efficient in translocating $\mathrm{Cr}$ from roots to shoots. Plant death occurred when higher metal concentrations were used (Ramana et al. 2015).

Buddleja asiatica is known to display a high accumulation capacity and tolerance for lead. This species, and the related ornamental B. paniculata, were therefore investigated in a hydroponic culture, in the presence of 10 or $20 \mathrm{mg} \mathrm{L}^{-1} \mathrm{~Pb}$. Both species showed increased biomass and $\mathrm{Pb}$ concentrations in the roots of 12.1 and $21.7 \mathrm{mg} \mathrm{kg}^{-1}$, respectively. In a 3-month pot experiment, using three different soils with various $\mathrm{Pb}$ levels (10.6, 31.3, and $89.1 \mathrm{mg} \mathrm{kg}^{-1}$ ) the two species of Buddleja had a slight decrease in survival rates at the highest $\mathrm{Pb}$ concentration, but a general regular growth. In a 6month field trial experiment conducted in Pb-contaminated sites ( $\mathrm{Pb}$ content: 95-101 $\mathrm{mg} \mathrm{kg}^{-1}$ ), both Buddleja species showed $100 \%$ survival, increased biomass production and phytoextraction capacity (TF) from 1.1 to 2.3 (Waranusantigul et al. 2008). Ricinus communis, as well, showed the capacity to uptake nichel $(\mathrm{Ni})$ from contaminated soils, and was therefore classified as an accumulator (Adhikari \& Kumar 2012); this species also demonstrated a great potential for Cd removal, due to its features of fast growth, high biomass and considerable absorption and accumulation (Huang et al. 2011).

It is more common for a soil to be affected by the pollution of a mix of heavy metals; some case studies are therefore reported below concerning woody plants.

In a pot experiment with seven willow clones, significant differences between clones were found in cadmium and zinc accumulation. $\mathrm{Cd}$ and $\mathrm{Zn}$ were transferred from roots to aboveground tissues (mainly leaves), leading to the conclusion that willows are suitable phytoextractors of moderately contaminated soils (Vyslouzilová et al. 2003). Another study tested the ability of five woody species to extract heavy metals (copper, zinc or cadmium) from a polluted soil. Salix viminalis and Betula pendula had already demonstrated phytoextraction ability for $\mathrm{Zn}$ and $\mathrm{Cd}$, while the phytoextraction capabilities of Alnus incana, Fraxinus excelsior and Sorbus mougeotii were unknown. The results suggest that none of these species transferred $\mathrm{Cu}$ to the shoots. Salix and Betula were able to transfer $\mathrm{Zn}$ and $\mathrm{Cd}$ to leaves and twigs, while Al- 
nus, Fraxinus and Sorbus excluded them from their above-ground tissues (Rosselli et al. 2003). A pot experiment involving Salix miyabeana grown in brownfield soils differentially contaminated with $\mathrm{Ag}, \mathrm{Cu}$ and $\mathrm{Zn}$ (up to 113.60, 47.50, and $117.00 \mathrm{mg}$ $\mathrm{kg}^{-1}$ respectively), demonstrated a potential capability for phytoremediation, since a high concentration of $\mathrm{Zn}(119.96 \pm 20.04$ $\mathrm{mg} \mathrm{kg}^{-1}$ ) was detected in above-ground plant tissues at the end of the treatment (Desjardins et al. 2016).

Five species of Salix were tested in a pot experiment to compare their capacity to extract and accumulate $\mathrm{Cd}, \mathrm{Zn}, \mathrm{Cu}, \mathrm{Ni}, \mathrm{Pb}$, and chromium (Cr). Salix schwerinii "Christina", S. dasyclados "Loden" and S. fragilis "Belgisch Rood" showed the highest $\mathrm{Cd}$ and $\mathrm{Zn}$ accumulation and were therefore considered good candidates for remediation (Meers et al. 2007). In an experiment on a strongly polluted soil (up to $18 \mathrm{mg} \mathrm{Cd} \mathrm{kg}{ }^{-1}, 1400 \mathrm{mg} \mathrm{Cu} \mathrm{kg}^{-1}, 500 \mathrm{mg} \mathrm{Pb}$ $\mathrm{kg}^{-1}$ and $3300 \mathrm{mg} \mathrm{Zn} \mathrm{kg}^{-1}$ ), Salix viminalis demonstrated a high translocation of $\mathrm{Cd}$ $\left(\geq 80 \mathrm{mg} \mathrm{kg}^{-1}\right)$ and zinc $\left(\geq 3000 \mathrm{mg} \mathrm{kg}^{-1}\right)$ to the leaves alongside reduced growth. In contrast, when grown in a moderately polluted soil $\left(2.5 \mathrm{mg} \mathrm{Cd} \mathrm{kg}^{-1}\right.$ and $400 \mathrm{mg} \mathrm{Zn}$ $\left.\mathrm{kg}^{-1}\right)$, S. viminalis extracted $0.13 \%$ of total $\mathrm{Cd}$ and $0.29 \%$ of total $\mathrm{Zn}$ per year and exhibited vigorous growth (Jensen et al. 2009). In another study on eight Salix viminalis clones and one S. alba clone, differences emerged between clones in biomass production and accumulation efficiency, with two S. viminalis clones demonstrating a superior capacity to accumulate five heavy metals (Cd, Cu, Hg, Pb, Zn - Mleczek et al. 2010).

Poplars also showed some potential for phytoextraction of chromium and iron ( $\mathrm{Gi}$ achetti \& Sebastiani 2006), cadmium and lead (Houda et al. 2016).

The accumulation of heavy metals has been assessed in leaves of some ornamental trees and shrubs used in districts of Turkey affected by high heavy metal pollution, finding significant differences among the tested species. The highest concentrations $\left(\mathrm{mg} \mathrm{kg}^{-1}\right.$ ) of $\mathrm{Zn}, \mathrm{Cu}, \mathrm{Cd}$ and iron (Fe) were observed in Cedrus libani (618.0), Betula alba (106.3), Salix alba (24.5) and Eleagnus angustifolia (0.3), while the highest $\mathrm{Ni}$ (6.4) and $\mathrm{Pb}$ (3.8) contents were found in Pyracantha coccinea (Gülser et al. 2011).

A pot experiment was carried out on osmanthus (Osmanthus fragrans var. thunbergii), cultured in substrate supplemented with different concentrations of $\mathrm{Cd}, \mathrm{Pb}, \mathrm{Zn}$, and $\mathrm{Cu}$. The species showed high $\mathrm{Cd}$ and $\mathrm{Pb}$ transfer efficiencies and a limited transfer of $\mathrm{Zn}$ and $\mathrm{Cu}$ in the presence of $\mathrm{Cd}$, suggesting the possible utilization of osmanthus in phytoremediation applications ( $\mathrm{Wu}$ et al. 2011).

\section{Herbaceous species}

Cadmium is one of the most widespread contaminating metals in soils. Its action was investigated on three ornamental

Tab. 2 - Ornamental plants for the phytoremediation of heavy metals: herbaceous species. (A): accumulation; $(T)$ : translocation.

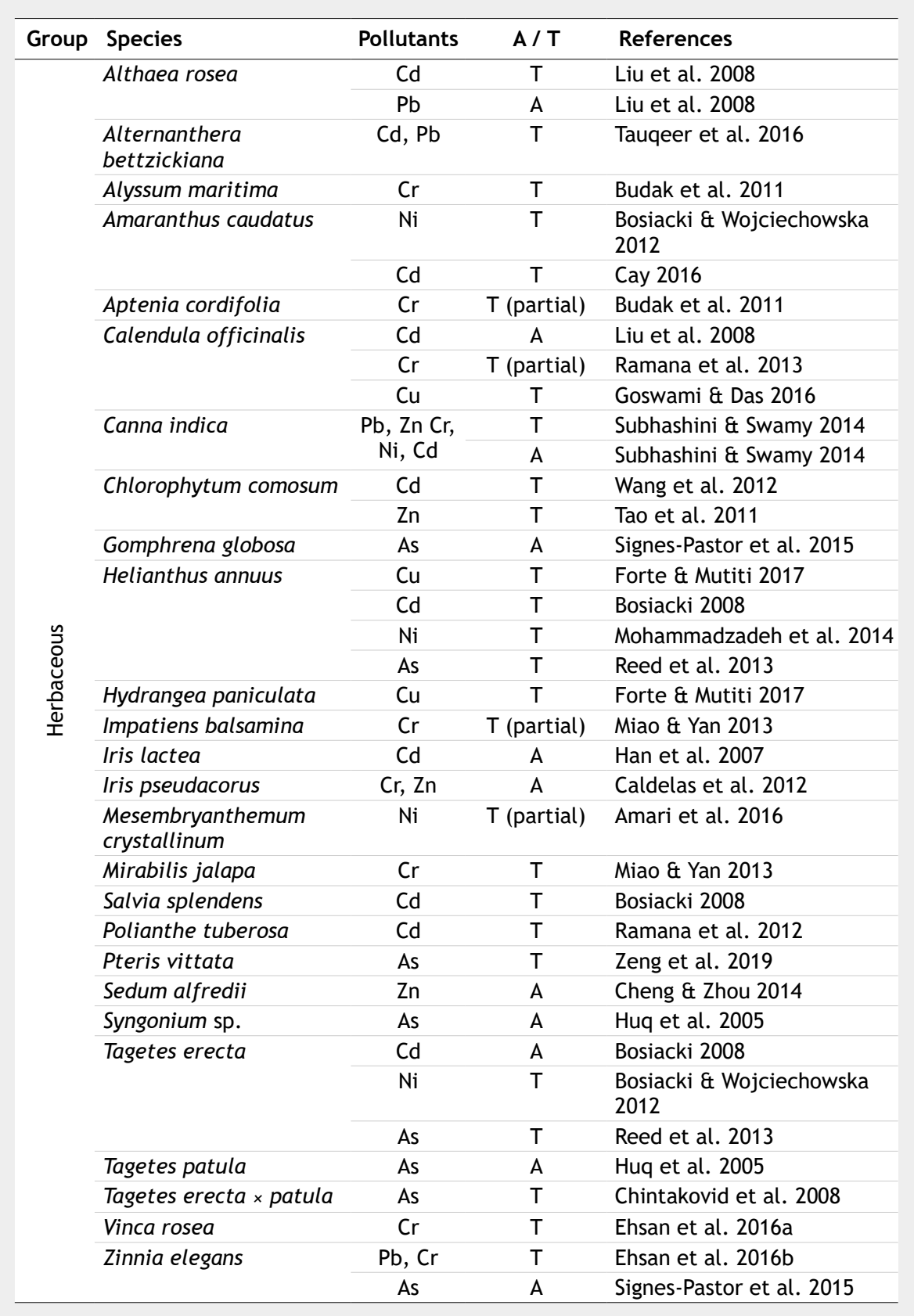

plants, Tagetes erecta, Salvia splendens, and Abelmoschus manihot, finding a little effect on seed germination of the three species and on shoot elongation of S. splendens, but a significant inhibitory effect on root elongation of all the tested plants and on shoot elongation of $T$. erecta. The calculated Cd-tolerance indices led to the conclusion that $A$. manihot was the most tolerant plant to $\mathrm{Cd}$ while $\mathrm{S}$. splendens the most sensitive (Wang \& Zhou 2005). Conversely, Bosiacki (2008) found high Cd accumulation in leaves and shoots of Salvia splendens, as well as in inflorescences of Helianthus annuus, which is one of the most studied ornamental species for remediation purposes, while Tagetes erecta proved a moderate capacity to extract and accumulate $\mathrm{Cd}$, with the greatest amount found in roots, then in leaves and shoots, and the lowest in inflorescences (Bosiacki 2008). Five concentrations of $\mathrm{Cd}(0,25,50$, 75 and $100 \mathrm{mg} \mathrm{kg}^{-1}$ soil) were tested with three varieties of tuberose, finding that this metal did not produce any toxic macroscopic symptoms in all the three varieties. Having shown $\mathrm{Cd}$ accumulation in the shoots higher than $100 \mu \mathrm{g} \mathrm{g}^{-1}$ dry weight and a ratio of $\mathrm{Cd}>1$ in the shoots to bulbs, this species has to be considered as a potential effective $\mathrm{Cd}$ accumulator (Ramana et al. 2012). Chlorophytum comosum is a potential Cd accumulator; in a pot experiment it showed a $\mathrm{Tl}$ above 100 in soil $\mathrm{Cd}$ concentration of $100 \mathrm{mg} \mathrm{kg}^{-1}$, and at Cd concentration up to $200 \mathrm{mg} \mathrm{kg}^{-1}$, the $\mathrm{Cd}$ content in roots and aboveground tissues reached 1522 and $865 \mathrm{mg} \mathrm{kg}^{-1}$, respectively (Wang et 
al. 2012). A detailed work on the relation between Canna indica and $\mathrm{Cd}$, demonstrated its considerable potential in cadmium accumulation, but the root concentration factor was higher than the $\mathrm{BF}$, indicating a limited translocation (Solanki et al. 2018). Calendula officinalis was found to grow normally in soils containing $100 \mathrm{mg}$ $\mathrm{kg}^{-1} \mathrm{Cd}$, with high metal accumulation in roots and shoots. In a hydroponic culture, for Althaea rosea the highest $\mathrm{Cd}$ accumulation was detected in shoots, and for both Calendula officinalis and Althaea rosea, a good accumulation capacity and tolerance to $\mathrm{Pb}$ were also observed (Liu et al. 2008) Iris lactea var. chinensis was found to accumulate $\mathrm{Cd}$ in leaves and roots after treat ment with a hydroponic culture with 0 to $160 \mathrm{mg} \mathrm{L}^{-1} \mathrm{Cd}$ treatment, showing a $\mathrm{T}$ higher than the value detected in the other species tested, I. tectorum (Han et al. 2007).

The effects of increasing doses of $\mathrm{Ni}$ (up to $300 \mathrm{mg} \mathrm{dm}^{-3}$ substrate) were investigated in three selected ornamental plants: Tagetes erecta, Helianthus annuus, and Amaranthus caudatus, finding that the highest amounts of $\mathrm{Ni}$ were accumulated in leaves of tagetes and amaranth, and in inflorescences of sunflower. Globally, tage tes showed the highest $\mathrm{Ni}$ uptake at concentrations of 25 and $50 \mathrm{mg} \mathrm{dm}^{-3}$, while for the substrates with an addition of 75, 150 or $300 \mathrm{mg} \mathrm{Ni} \mathrm{dm}^{-3}$, the greatest accumulation was recorded in amaranth (Bosiacki \& Wojciechowska 2012). An interesting ornamental halophyte, Mesembryanthemum crystallinum, was compared to the mode species Brassica juncea, growing the plants for 3 months on a soil containing $0,25,50$, and $100 \mathrm{mg} \mathrm{kg}^{-1} \mathrm{NiCl}_{2}$. $\mathrm{Ni}$ reduced the growth activity of both species, but to a lower extent in $M$. crystallinum. $\mathrm{Ni}$ accumulated mainly in roots and the fraction translocated to shoots was higher in $M$ crystallinum than in B. juncea (Amari et al. 2016). Catharanthus roseus irrigated for 60 days with aqueous solutions of nickel and lead showed high accumulation of the two metals by roots, and to a lesser extent in stems and leaves (Subhashini \& Swamy 2013).

Chlorophytum comosum seedlings treated with $\mathrm{Zn}$ showed inhibition of root length and fresh and dried plant weight at all the tested $\mathrm{Zn}$ concentrations (from 200 to $2000 \mathrm{mg} \mathrm{kg}^{-1}$ ), while the length of above ground tissues and the volume of roots declined with the $\mathrm{Zn}$ dose. TI was above 50 at $\mathrm{Zn}$ concentrations lower than $600 \mathrm{mg} \mathrm{kg}$ (Tao et al. 2011).

Aptenia cordifolia, Brassica juncea, Bras sica oleracea, and Alyssum maritima were studied for their capacity to uptake and translocate hexavalent chromium (VI) sup plied by irrigation. Increases in the $\mathrm{Cr}$ concentration significantly enhanced both ac cumulation and translocation of the metal in the roots and shoots of the tested species, with highest values recorded in the shoots of Alyssum maritima and in the roots of Brassica juncea (Budak et al. 2011). In a study on exposure to $\mathrm{Cr}$ of four ornamental plants, calendula, chrysanthemum, aster and dahlia, the metal caused a drastic reduction of plant growth at $10 \mathrm{mg} \mathrm{kg}^{-1}$, and at $25 \mathrm{mg} \mathrm{kg}^{-1}$ was responsible of a diffuse mortality in chrysanthemum. Overall, only calendula could be considered a possible candidate for phytoremediation of soils contaminated with low level of $\mathrm{Cr}$ (Ramana et al. 2013). In another experiment on three ornamental species cultured in pots containing substrate with four $\mathrm{Cr}$ concentrations, Impatiens balsamina showed a decline in the biomass as the dose of $\mathrm{Cr}$ increased, while in Mirabilis jalapa and Tagetes erecta the four treatments did not impact growth; TF and BF of $M$. jalapa were greater than 1, indicating this species is a good candidate for the remediation of $\mathrm{Cr}$ polluted soils (Miao \& Yan 2013). In Vinca rosea grown in pots containing soil with levels of chromium from 10 to $60 \mathrm{mg} \mathrm{kg}^{-1}$, plant height, fresh and dry weight decreased with high contamination levels of chromium. TFs were found to be lower than 1 for low metal concentrations and higher than 1 with $\mathrm{Cr}$ concentrations from 30 to $60 \mathrm{mg} \mathrm{kg}^{-1}$ (Ehsan et al. 2016a).

In the presence of $\mathrm{Pb}$, the remediation potential of Vinca rosea was higher than 1 at $\mathrm{Pb}$ concentrations from 20 to $40 \mathrm{mg} \mathrm{kg}^{-1}$ and lower with 50 to $90 \mathrm{mg} \mathrm{kg}^{-1}$ (Ehsan et al. 2016b). Similar results were obtained with zinnia (Zinnia elegans) grown in pots containing soils with different levels of lead and chromium. Plants grown in the presence of lead were healthier compared to plants grown in $\mathrm{Cr}$-contaminated soils. TF was also higher in $\mathrm{Pb}$-contaminated soils (Ehsan et al. 2016C).

For copper remediation, Calendula officinalis showed a high tolerance (up to 400 $\mathrm{mg} \mathrm{kg}^{-1}$ ) to copper contamination, with the maximum $\mathrm{Cu}$ accumulation (4.67 and 3.99 $\mathrm{mg} \mathrm{g}^{-1}$ in leaves and roots, respectively) in soil treated with $300 \mathrm{mg} \mathrm{Kg}^{-1}$, a level considerably higher than the amount of $1 \mathrm{mg}$ $\mathrm{g}^{-1}$ which defines $\mathrm{Cu}$ hyperaccumulators (even the TF was $>1$ at all Cu doses - Goswami \& Das 2016).

For arsenic remediation, Tagetes patula and Syngonium sp. were tested in pots with soil containing As up to $10 \mathrm{mg} \mathrm{kg}$. The plants showed significant As accumulation, particularly in roots, with an average TF of 0.91 for marigold and 0.75 for arum (Huq et al. 2005). A further experiment on a triploid hybrid Tagetes erecta $\times$ patula showed that arsenic was found mostly in leaves (46.2\%) with the lowest As content $(5.8 \%)$ in flowers. The hybrid plants continued to grow vigorously in the As-contaminated substrate (Chintakovid et al. 2008). Several ornamental plant species were tested for their potential for As remediation in a hydroponic system: iris (Iris savannarum), switchgrass (Panicum virgatum), Tithonia rotundiflora, Coreopsis lanceolata, sunflower (Helianthus annuus), and marigold (Tagetes erecta). Tithonia and Coreop- sis showed respectively $85 \%$ and $65 \%$ reductions in dry weight at $0.75 \mathrm{mg} \mathrm{L}^{-1}$ As concentration. At the highest As rate, marigold and sunflower had uptake ratios of 7.4 and 16.6, respectively, and TF near one, allowing consideration of these species as interesting candidates for As phytoremediation (Reed et al. 2013).

The effects of As were tested under hydroponic conditions on two other flowering species, Gomphrena globosa and Zinnia elegans. Arsenic principally accumulated in the roots, followed by leaves, stems and flowers, indicating that these species were arsenic tolerant plants but not potentially As-remediating (Signes-Pastor et al. 2015).

For the phytoremediation of mixed heavy metals, a study on Alternanthera bettzickiana, a species commonly used as an ornamental edging plant, showed a good accumulation of $\mathrm{Cd}$ and $\mathrm{Pb}$ at concentrations up to $1.0 \mathrm{mM}$, with total uptake of both metals higher in shoots than roots (Tauqeer et al. 2016). Based on BF and TF, also Canna indica was indicated to be a good accumulator of $\mathrm{Cd}, \mathrm{Pb}, \mathrm{Ni}, \mathrm{Zn}$, and $\mathrm{Cr}$, with high TF for Ni and $\mathrm{Cr}$ (Subhashini \& Swamy 2014). The macrophyte Iris pseudacorus is considered to be a candidate for $\mathrm{Cr}$ rhizofiltration and $\mathrm{Zn}$ phytoextraction, having shown a good tolerance and accumulation capacity towards these two metals. Plants grown in a nutrient solution containing $\mathrm{ZnCl}_{2}$ or $\mathrm{CrCl}_{3}$ from o to $200 \mu \mathrm{g} \mathrm{ml}^{-1}$ survived and accumulated $\mathrm{Cr}$ and $\mathrm{Zn}$ in all tissues (Caldelas et al. 2012). In a greenhouse experiment, Hydrangea paniculata and Helianthus annuus accumulated significant amounts of $\mathrm{Cu}$ and $\mathrm{Pb}$. Helianthus showed high accumulation of heavy metals in the shoots and efficacious translocation to the leaves, while $\mathrm{Pb}$ was not as easily taken up and translocated as $\mathrm{Cu}$. Hydrangea stored more metals in stems than in leaves, showing a lower translocation ability than Helianthus (Forte \& Mutiti 2017). Tanacetum vulgare showed environmental adaptability on high industrial pollution and an interesting capacity of mercure and lead uptake (Stevović et al. 2010).

\section{Organics}

Phytoremediation of organic contaminants generally involves few classes of compounds, which are principally chlorinated solvents, petroleum hydrocarbons (PHCs), polycyclic aromatic hydrocarbons (PAHs), polychlorinated biphenyls (PCBs) and explosives. Contamination of soils with such products can have several causes, the main ones being uncontrolled industrial activity, intensive farmland exploitation and percolation of polluted waters of various origins. The most common contaminated soils are probably former industrial sites, which may display residual pollutants at different soil depths.

Over recent years, positive results have emerged regarding the capacities of several plant species to degrade specific organic compounds. According to Shimp et al. (1993) it is fundamental to understand 
the physical, biological, and chemical relationships that determine the fate of each organic contaminant in the rhizosphere.

In this section some case examples concerning ornamental woody and herbaceous species are illustrated (Tab. 3 ).

\section{Woody species}

In a soil contaminated with a mix of PAHs, PCBs and heavy metals, two clones of different willow species (Salix sachalinensis SX61 and S. miyabeana SX64) gave encouraging growth and survival results after a single growing season planted in soils with high concentrations of both organic and heavy metal contaminants (Guidi et al. 2012). Salix alba, S. gracilistyla var. melanostachys and Itea virginica were treated for 9 days with a $4 \mathrm{mg} \mathrm{L}^{-1}$ suspension of two herbicides (isoxaben and oryzalin). Isoxaben reduced the growth rate of white willow and $I$. virginica, while both herbicides reduced the growth index for S. gracilistyla. The final dry weight was lower for all taxa when exposed to both herbicides, but the set of data suggest that S. alba and I. virginica display some attitude in the remediation of oryzalin (Baz \& Fernandez 2002).

In hydroponic studies, hybrid poplar cuttings (Populus deltoides $\times$ nigra) removed $54.0 \%$ of dioxane (1,4-Dioxane), a persistent environmental pollutant, indicating the potential of this species in the phytoremediation of sites contaminated by dioxane and other hydrophilic pollutants (Aitchison et al. 2000). P. deltoides $\times$ nigra showed also the capacity to accumulate PCBs, observing that mono- and di-chlorinated congeners were primarily translocated from the roots to the secondary stems, tri-chlorinated to the main stem but not farther, and tetra-chlorinated were bound strongly to root tissues (Liu \& Schnoor 2008). With the same hybrid, the capacity to uptake, hydrolyze and dealkylate atrazine to less toxic metabolites was detected by Burken \& Schnoor (1997).

Nerium oleander (Fig. 3b) resulted able to remove $92 \%$ of fluoride from a $10 \mathrm{mg} \mathrm{L}^{-1} \mathrm{NaF}$ solution, within 15 days (Khandare et al. 2017). Ricinus communis showed a great potential for removing dichlorodiphenyltrichloroethane (DDT) from contaminated soils, with different effectiveness depending on the genotype (Huang et al. 2011).

\section{Herbaceous species}

In a study on Aster amellus, the capacity was observed to decolorize the sulfonated azo dye Remazol Red. After the cultivation period, four non-toxic metabolites were identified; this indicated that the plant can be used for cleaning textile effluents (Khandare et al. 2011). In another study on phytoremediation of dyes from textile wastewater, Tagetes patula, Aster amellus, Portulaca grandiflora and Gaillardia grandiflora were tested separately, finding that within 30 days they reduced the color value by $59,50,46$ and $73 \%$, respectively. Only a minor decrease in plant growth was

Tab. 3 - Ornamental plants for the phytoremediation of organic compounds. (B[a]P): benzo[a]pyrene; (DDT): dichlorodiphenyltrichloroethane; $(\mathrm{HCH})$ : hexachlorocyclohex ane; $(\mathrm{PCB})$ : polychlorinated biphenyls; $(\mathrm{PAH})$ : polycyclic aromatic hydrocarbons; (TCE): trichloroethylene; (TPH): total petroleum hydrocarbons.

\begin{tabular}{|c|c|c|c|}
\hline Group & Species & Pollutants & References \\
\hline \multirow{9}{*}{ 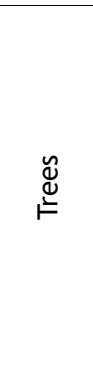 } & Itea virginica & Oryzalin & Baz \& Fernandez 2002 \\
\hline & \multirow[t]{4}{*}{ Populus deltoides $\times$ nigra } & TCE & Doty et al. 2017 \\
\hline & & Dioxane & Aitchison et al. 2000 \\
\hline & & PCB & Liu \& Schnoor 2008 \\
\hline & & Atrazine & Burken \& Schnoor 1997 \\
\hline & Populus hybrids & $\mathrm{HCH}$ & Bianconi et al. 2011 \\
\hline & Salix alba & Oryzalin & Baz \& Fernandez 2002 \\
\hline & Salix miyabeana & $\mathrm{PAH}, \mathrm{PCB}$ & Guidi et al. 2012 \\
\hline & Salix sachalinensis & PAH, PCB & Guidi et al. 2012 \\
\hline \multirow{3}{*}{$\begin{array}{l}\frac{n}{2} \\
\frac{2}{\sim}\end{array}$} & Cytisus striatus & $\mathrm{HCH}$ & Becerra-Castro et al. 2013 \\
\hline & Nerium oleander & Fluoride & Khandare et al. 2017 \\
\hline & Ricinus communis & DDT & Huang et al. 2011 \\
\hline \multirow{18}{*}{$\begin{array}{l}n \\
\overline{0} \\
\mathbb{U} \\
\tilde{\pi} \\
\frac{0}{0} \\
\text { I }\end{array}$} & Aloe vera & Formaldehyde & Liu et al. 2007 \\
\hline & Aster amellus & Dyes & Khandare et al. 2011 \\
\hline & Canna indica & Triazophos & Cheng et al. 2007 \\
\hline & Chrisanthemum morifolium & $\begin{array}{l}\text { Benzene, } \\
\text { Formaldehyde }\end{array}$ & Liu et al. 2007 \\
\hline & Crassula portulacea & Benzene & Liu et al. 2007 \\
\hline & Dianthus chinensis & Sulfur dioxide & Liu et al. 2007 \\
\hline & Echinacea purpurea & TPH & Liu et al. 2012 \\
\hline & Festuca arundinacea & $\mathrm{TPH}$ & Liu et al. 2012 \\
\hline & Gaillardia aristata & $\mathrm{TPH}$ & Liu et al. 2012 \\
\hline & Gaillardia grandiflora & Dyes & Chandanshive et al. 2018 \\
\hline & Impatiens balsamina & $\mathrm{TPH}$ & Cai et al. 2010 \\
\hline & Iris lactea & TPH & Cheng et al. 2017 \\
\hline & Medicago sativa & $\mathrm{TPH}$ & Liu et al. 2012 \\
\hline & Mirabilis jalapa & $\mathrm{B}[\mathrm{a}] \mathrm{P}$ & Sun \& Zhou 2016 \\
\hline & Portulaca grandiflora & Dyes & Chandanshive et al. 2018 \\
\hline & Portulaca oleracea & Fluoride & Khandare et al. 2017 \\
\hline & Tagetes patula & Dyes & Chandanshive et al. 2018 \\
\hline & & $B[a] P$ & Sun \& Zhou 2016 \\
\hline
\end{tabular}

observed, suggesting that these ornamental species could be an interesting solution for use on the ridges of constructed wetland for the treatment of dyes (Chandanshive et al. 2018).

Tagetes patula and Mirabilis jalapa were tested in a pot experiments to evaluate their remediation capacity towards benzo[a]pyrene $(\mathrm{B}[\mathrm{a}] \mathrm{P})$. The dry biomass of the two species increased at low $B[a] P$ doses and then reduced with increasing concentrations. It also emerged that the tolerance to this pollutant was greater at the plant's flowering and mature stages compared with the seedling stage. Significantly positive correlations were found between the $B[a] P$ content of roots, stems, leaves and shoots to soil B[a]P concentrations (Sun \& Zhou 2016).

For the treatment of PHCs-contaminated soil, Iris dichotoma and I. lactea were investigated in a pot culture experiment. These species were found to promote degradation of fractions of PHCs. I. lactea tolerated high concentration of PHCs $(40,000 \mathrm{mg}$ $\mathrm{kg}^{-1}$ ) and showed a good degradation rate of petroleum hydrocarbons. In contrast, I. dichotoma tolerated lower PHC concentrations, with a lower rate of total petroleum hydrocarbons (TPHs) degradation (Cheng et al. 2017). Impatiens balsamina was also tested for petroleum remediation, finding that after a 4-month culture period in pot, the average TPHs degradation rate was up to $18.13-65.03 \%$, greater than that $(10.20-$ $35.61 \%$ ) of natural degradation in the control treatment (Cai et al. 2010).

In a pot-culture experiment to assess the TPHs-phytoremediation potential of 14 ornamental plants in petroleum-contaminated soil, it emerged that Gaillardia aristata, Echinacea purpurea, Festuca arundinacea and Medicago sativa were effective in reducing TPHs (and related compounds) in $10 \mathrm{mg} \mathrm{kg}^{-1} \mathrm{TPH}$-contaminated soil. Removal rates after 30 days were between 37.2 and $49.4 \%$, (control only $12.9 \%$ ). Removal rates of TPH composition were also significantly higher than controls, and Fourier transform infrared spectroscopy confirmed the presence of oil in the plant tissues (Liu et al. 2012).

Plants of Portulaca oleracea were able to remove fluoride from a $10 \mathrm{mg} \mathrm{L}^{-1} \mathrm{NaF}$ solu- 
tion, within 15 days by $73 \%$; the higher fluoride concentrations showed lower removal rates (Khandare et al. 2017). Canna indica was studied in a hydroponic system for testing its ability to remediate triazophos contamination, a harmful pesticide. After 21 days of exposure, a significant percentage of the substance was removed from the substrate (Cheng et al. 2007). Among numerous other cases, Chrysanthemum morifolium can simultaneously absorb and purify benzene and formaldehyde to a large extent, while Aloe vera var. chinensis can absorb formaldehyde; Crassula portulacea is active towards benzene, and Dianthus chinensis towards sulfur dioxide (Liu et al. 2007).

Wild ornamentals with high ornamental value, fast growth and extensive root systems are, in general, a suitable solution, when deemed capable of degrading contaminants, due to their broad adaptability, widespread distribution and ease of cultivation (Cheng \& Zhou 2014).

\section{Consociations}

Soils are often polluted by different metals or organic compounds, so phytoremediation may require multiple plant species and ecotypes since most of the plants suited to this purpose show an aptitude to accumulate only one or a few pollutants.

A pot experiment was carried out with the aim of determining the phytoextraction potential of the hyperaccumulator Pteris vittata when co-planted with a woody tree (Morus alba or Broussonetia papyrifera) in soil contaminated with $\mathrm{Cd}, \mathrm{Pb}$, $\mathrm{Zn}$, or As. The uptake of As was significantly increased when co-planted with Morus or Broussonetia (by $80.0 \%$ and $64.2 \%$ respectively). However, co-plantation did not have a promoting effect on the metal accumulation of both M. alba L. and B. papyrifera (Zeng et al. 2019).

In the case a huge expanse of land, a consociation of grasses could be a good solution. Work by Maila et al. (2005) demonstrated the potential of the grass species Brachiaria serrata and Eleusine corocana in decontaminating PAHs-contaminated soil. It was found that after a ten-week treatment the naphthalene concentration was undetectable in the "multispecies" vegetated soil compared to $96 \%$ removal efficiency in the monoplanted treatment and $63 \%$ in the control. For the same contaminants, ryegrass (Lolium perenne), white clover (Trifolium repens) and celery (Apium graveolens) were tested, finding that the remaining percentage of PAHs in mixtures was significantly lower than those in monocultures and non-planted soils (Meng et al. 2011). Another work proved that Brassica campestris showed low removal of PAHs, while Medicago sativa had the highest potential for remediation of phenanthrene and Trifolium repens for pyrene; but mixed cropping (rape with white clover or alfalfa, Medicago sativa) showed far better results than single cropping for the remediation of
PAHs (Wei \& Pan 2010).

Concerning polychlorinated biphenyls (PCB), Terzaghi et al. (2019) demonstrated that Festuca arundinacea cultivated by adding compost or in consociation with $\mathrm{Cu}$ curbita pepo ssp. pepo and Medicago sativa cultivated with Rhizobium spp. and mycorrhizal fungi reduced total PCB concentrations by about $20 \%$, with a significant depletion in a high number of PCB congeners. In an in vitro experiment, Petunia grandiflora and Gaillardia grandiflora, when cultured together, showed a great effectiveness in degrading and removing a dye mixture from the substrate in $36 \mathrm{~h}$, with results significantly higher than those detected from the cultivars in isolation (Watharkar \& Jadhav 2014).

\section{Enhanced phytoremediation}

It is worth noting that, for several tree species, the plant-fungi-bacterium system represents an important interactive balance for the implementation of the phytoremediation activity, as recently observed in hybrid poplar (Populus deltoides $x$ P. nigra) and willow (Salix purpurea subsp. lambertiana - Guarino et al. 2018). Eucalyptus camaldulensis also demonstrated increased effectiveness in extraction, uptake, and translocation of $\mathrm{Cd}$ when inoculated with arbuscular mycorrhiza fungi or plant growth promoting rhizobacteria (Motesharezadeh et al. 2017). As an example for herbaceous species, Helianthus annuus inoculated with Bacillus safensis and/or Kocuria rosea was tested in soil with four levels of $\mathrm{Ni}$ concentrations $(0,150,300$, and $450 \mathrm{mg} \mathrm{kg}^{-1}$ ), finding that the highest $\mathrm{Ni}$ uptake was observed at $\mathrm{Ni} \mathrm{300,} \mathrm{when} \mathrm{the}$ sunflower seed was co-inoculated by $B$. safensis + K. rosea (Mohammadzadeh et al. 2014).

With regard to organic pollutants, endophyte-assisted phytoremediation of a site contaminated with Trichloroethylene (TCE) was studied using Populus deltoides $\times$ nigra inoculated with a strain of Enterobacter. The inoculated trees showed an increased growth and a reduced toxic effect compared to control, excreting 50\% more chloride ions into the rhizosphere, a good signal of an increased TCE metabolism in planta. A significant decrease in the concentration of TCE and its derivatives from the tree-associated groundwater plume was also detected (Doty et al. 2017). With hybrid poplar clones associated to Arthrobacter strains, the possibility to rhizoremediate soils contaminated with the insecticide exachlorocyclohexane $(\mathrm{HCH})$ isomers was demonstrated, stressing the importance of in situ pre-selection of the best candidate plants and bacteria strains (Bianconi et al. 2011). The shrub Cytisus striatus, also in association with microbial inoculants (Rhodococcus erythropolis and Sphingomonas sp.) showed an interesting activity on the dissipation of the $\mathrm{HCH}$. $\mathrm{HCH}$ concentration in soil was reduced after plant growth and, more significantly, with inoculated plants
(Becerra-Castro et al. 2013).

Many studies assess the remediation of metal-polluted soil with the help of several agents, mainly synthetic organic chelates, but also natural organic compounds and inorganic products, that overcome limitations to phytoremediation due to low metal solubility and availability (Leštan et al. 2008). Nevertheless, the high cost of these products and the possible toxic outflow into the environment have to be taken into account. Below, a few cases are mentioned as examples.

The application to soil of sodium dodecyl sulfate (SDS), ethylenediaminetriacetic acid (EDTA) and ethylenegluatarotriacetic acid (EGTA) to enhance $\mathrm{Cd}$ remediation was studied with Calendula officinalis. EDTA was observed to be toxic to the plants, while the addition of SDS and/or EGTA resulted in significantly increased plant biomass $(p<0.05)$. Almost all of the treatments containing SDS or/and EGTA led to an increase in the total $\mathrm{Cd}$ content in the plants (Liu et al. 2010). For enhancing the uptake and translocation of $\mathrm{Cd}, \mathrm{Cr}$, and $\mathrm{Ni}$, two cultivars of Helianthus annuus were used in conjunction with EDTA and citric acid (CA) as chelators. EDTA at a concentration of $0.1 \mathrm{~g} \mathrm{~kg}^{-1}$ produced the best results for both cultivars, while the highest CA concentrations had a phytotoxic effect (Turgut et al. 2004). In Althaea rosea, EDTA and tannic acid led to higher heavy metal removal of $\mathrm{Cd}, \mathrm{Ni}, \mathrm{Pb}$ and $\mathrm{Cu}$ from an artificially contaminated soil, with significant heavy metal accumulation in stems and leaves (Cay et al. 2015).

In view of a more environmentally friendly choice, less harmful products can be used. Amaranthus caudatus showed an increased capacity to uptake cadmium when solutions of tea saponin (extracted from camellia seeds) or EDTA were supplied to the soil, detecting TF $>1$, with better values for saponin (Cay 2016). In a pot experiment with Helianthus annuus, the effects of culture in a soil contaminated with $\mathrm{Cd}$ and $\mathrm{Zn}$ and amended with swine manure, salicylic acid (SA), or potassium chloride $(\mathrm{KCl})$ were assessed. The three amendments increased sunflower biomass, height, and flower diameter. Manure significantly decreased the bioaccumulation coefficient (BCF) of $\mathrm{Cd}$ and $\mathrm{Zn}$, while $\mathrm{KCl}$ increased the $\mathrm{BCF}$ of $\mathrm{Cd}$. Either swine manure and $\mathrm{KCl}$ increased $\mathrm{Cd}$ and $\mathrm{Zn}$ translocation from roots to aboveground parts, while swine manure and $\mathrm{SA}$ reduced the $\mathrm{Cd} / \mathrm{Zn}$ ratios in flowers (Hao et al. 2012).

Within this wide frame, the development of transgenic plants with enhanced phytoremediation capacity is also a possible approach (Shah \& Pathak 2019), but the general opposition of public opinion to the introduction of genetically modified plant species has to be carefully considered.

\section{Conclusions}

The use of ornamental (woody and flowering) plants for the phytoremediation of 
urban and periurban environments shows many positive aspects that have been highlighted in this work. The "multipurpose" function of these plants plays an important role in the environmental restoration and aesthetic enhancement, but the success of the phytoremediation strategy lies in the careful choice of species and/or genotypes matching the specific environments and pollutants.

From the review of the available literature it emerged that, trees in general, even if not classifiable as hyperaccumulators, display a greater potential for exploitation in phytoremediation compared to herbaceous species. This is simply due to the greater biomass growth potential and rooting system depth of woody species. On the other hand, herbaceous species are characterised by higher variability and plasticity, and offer the possibility of frequent replacements.

Among trees, Salicaceae are probably the most investigated species for phytoremediation purposes (Marmiroli et al. 2011). Great interest is addressed to Salix spp., while poplars are now considered to be model species, comparable to Arabidopsis among herbaceous plants. Due to their adaptability to different environments, fast growth, ease of propagation and good performances when exposed to some pollutants, these species might possess some useful practical applications in phytoremediation, particularly in peri-urban areas. For urban environments, several other woody species are probably more suitable, being characterised by a higher ornamental value. Among flowering herbaceous plants, the possibility of choice is significantly wider; for instance, the Asteraceae family shows a wide range of interesting species (Nikolić \& Stevović 2015) with sunflowers having been studied in depth and demonstrating a high capacity to remediate specific pollutants.

Several interesting species are yet to be explored, and special attention should be paid to the huge possibilities offered by plant consociation, including aspects related to modifications in the structure of the rhizosphera. Within this topic, possible associations between herbaceous plants, trees or between herbaceous and woody plants are practically infinite, allowing a perfect adhesion to the needs of each specific environment, and making phytoremediation an "aesthetic experience", as proposed by Sleegers (2010).

Finally, efforts are required to overcome problems related to the disposal of contaminated materials and how to limit the costs related to the exploitation of this technique.

In synthesis, phytoremediation could now be seen as part of a multifunctional process that creates a green infrastructure network defining evolving landscapes, not only in the countryside but also in urban environments.

\section{Acknowledgements}

I gratefully acknowledge Mrs. Catia Boggi and Mr. Gabriele Cencetti for their cooperation in the information retrieval and for the images provided. The manuscript was greatly improved by the comments provided by two anonymous reviewers.

\section{References}

Abbasi H, Pourmajidian MR, Hodjati SM, Fallah A, Nath S (2017). Effect of soil-applied lead on mineral contents and biomass in Acer cappadocicum, Fraxinus excelsior and Platycladus orientalis seedlings. iForest - Biogeoscience and Forestry 10 (4): 722-728. - doi: 10.3832/ifor2251-010 Abrahams PW (2002). Soils: their implications to human health. Science of the Total Environment 291: 1-32. - doi: 10.1016/S0048-9697(01)011 02-0

Adhikari T, Kumar A (2012). Phytoaccumulation and tolerance of Ricinus communis L. to nickel. International Journal of Phytoremediation 14: 481-492. - doi: 10.1080/15226514.2011.604688

Aitchison EW, Kelley SL, Alvarez PJJ, Schoor JL (2000). Phytoremediation of 1,4-dioxane by hybrid poplar trees. Water Environment Research 72: 313-321. - doi: 10.2175/106143000X137536

Amari T, Ghnaya T, Sghaier S, Porrini M, Lucchini G, Sacchi AG, Abdelly C (2016). Evaluation of $\mathrm{Ni}^{2+}$ phytoextraction potential in Mesembryanthemum crystallinum (halophyte) and Brassica juncea. Journal of Bioremediation and Biodegradation 7 (2): 336. - doi: 10.4172/2155-6199.1000 336

Baz M, Fernandez RT (2002). Evaluating woody ornamentals for use in herbicide phytoremediation. Journal of the American Society for Horticultural Science 127 (6): 991-997. - doi: 10.21273/ JASHS.127.6.991

Becerra-Castro C, Kidd PS, Rodríguez-Garrido B, Monterroso C, Santos-Ucha P, Prieto-Fernández A (2013). Phytoremediation of hexachlorocyclohexane $(\mathrm{HCH})$-contaminated soils using Cytisus striatus and bacterial inoculants in soils with distinct organic matter content. Environmental Pollution 178: 202-210. - doi: 10.1016/j.en vpol.2013.03.027

Berndes G, Fredrikson F, Borjesson P (2004). Cadmium accumulation and Salix-based phytoextraction on arable land in Sweden. Agriculture, Ecosystem and Environment 103: 207-223. - doi: 10.1016/j.agee.2003.09.013

Bianconi D, De Paolis MR, Agnello AC, Lippi D, Pietrini F, Zacchini M, Polcaro C, Donati E, Paris P, Spina S, Massacci A (2011). Field-scale rhyzoremediation of a contaminated soil with hexachlorocyclohexane $(\mathrm{HCH})$ isomers: the potential of poplars for environmental restoration and economical sustainability. In: "Handbook of Phytoremediation" (Golubev IA ed). Nova Science Publishers, Inc, New York, USA, pp. 783-794.

Biasioli M, Barberis R, Ajmone-Marsan F (2006). The influence of a large city on some soil properties and metals content Science of the Total Environment 356: 154-164. - doi: 10.1016/j.scitot env.2005.04.033

Blaylock MJ, Huang JW (2000). Phytoextraction of metals. In: "Phytoremediation of Toxic Metals: Using Plants to Clean up the Environment" (Raskin I, Ensley BD eds). John Wiley and Sons,
New York, USA, pp. 53-70.

Boll T, Von Haaren C, Albert C (2014). How do urban dwellers react to potential landscape changes in recreation areas? A case study with particular focus on the introduction of dendromass in the Hamburg Metropolitan Region. iForest - Biogeoscience and Forestry 7 (6): 423433. - doi: 10.3832/ifor1173-007

Borghi M, Tognetti R, Monteforti G, Sebastiani L (2007). Responses of Populus $\times$ euramericana (P. deltoides $\times$ P. nigra) clone Adda to increasing copper concentrations. Environmental and Experimental Botany 61: 66-73. - doi: 10.1016/j.env expbot.2007.03.001

Bosiacki M (2008). Accumulation of cadmium in selected species of ornamental plants. Acta Scientiarium Polonorum Hortorum Cultus 7 (2): 2131.

Bosiacki M, Wojciechowska E (2012). Phytoextraction of nickel by selected ornamental plants. Ecological Chemistry and Engineering 19 (3): 331-345. - doi: 10.2478/v10216-011-0024-9 Bretzel F, Calderisi M (2006). Metal contamination in urban soils of coastal Tuscany (Italy). Environmental Monitoring and Assessment 118: 319-335. - doi: 10.1007/s10661-006-1495-5

Budak F, Zaimoglu Z, Basci N (2011). Uptake and translocation of hexavalent chromium by selected species of ornamental plants. Polish Journal of Environmental Studies 20: 857-862. [online] URL: http://www.researchgate.net/pu blication $/ 288111790$

Burken JG, Schnoor JL (1997). Uptake and metabolism of atrazine by poplar trees. Environmental Science and Technology 31: 1399-1406. doi: 10.1021/es960629v

Cachada A, Pato P, Rocha-Santos T, Ferreira Da Silva E, Duarte AC (2012). Levels, sources and potential human health risks of organic pollutants in urban soils. Science of Total Environment 430: 184-192. - doi: 10.1016/j.scitotenv.20 12.04.075

Cai Z, Zhou QX, Peng SW, Li KN (2010). Promoted biodegradation and microbiological effects of petroleum hydrocarbons by Impatiens balsamina L. with strong endurance. Journal of Hazardous Material 183: 731-737. - doi: 10.1016/j.jhaz mat.2010.07.087

Caldelas JL, Araus A, Febrero J (2012). Accumulation and toxic effects of chromium and zinc in Iris pseudacorus L. Acta Physiologiae Plantarum 34: 1217-1228. - doi: 10.1007/s11738-012-0956

Carrus G, Scopelliti M, Lafortezza R, Colangelo G, Ferrini F, Salbitano F, Agrimi M, Portoghesi L, Semenzato P, Sanesi G (2015). Go greener, feel better? The positive effects of biodiversity on the well-being of individuals visiting urban and peri-urban green areas. Landscape and Urban Planning 134: 221-228. - doi: 10.1016/j.landurb plan.2014.10.022

Cay S (2016). Enhancement of cadmium uptake by Amaranthus caudatus, an ornamental plant, using tea saponin. Environmental Monitoring and Assessment 188: 1-8. - doi: 10.1007/s10661016-5334-z

Cay S, Uyanik A, Engin MS, Kutbay HG (2015). Effect of EDTA and tannic acid on the removal of $\mathrm{Cd}, \mathrm{Ni}, \mathrm{Pb}$ and $\mathrm{Cu}$ from artificially contaminated soil by Althaea rosea Cavan. International Journal of Phytoremediation 17 (1-6): 568-574. - doi: 10.1080/15226514.2014.935285 
Chandanshive VV, Kadam SK, Khandare RV, Kurade $\mathrm{MB}$, Jeon $\mathrm{BH}$, Jadhav JP, Govindwar SP (2018). In situ phytoremediation of dyes from textile wastewater using garden ornamental plants, effect on soil quality and plant growth. Chemosphere 210: 968-976. - doi: 10.1016/j.che mosphere.2018.07.064

Chen B, Adimo OA, Bao Z (2009). Assessment of aesthetic quality and multiple functions of urban green space from the users' perspective: the case of Hangzhou Flower Garden, China. Landscape and Urban Planning 93 (1): 76-82. doi: 10.1016/j.landurbplan.2009.06.001

Cheng L, Wang Y, Cai Z, Liu J, Yu B, Zhou Q (2017). Phytoremediation of petroleum hydrocarbon-contaminated saline-alkali soil by wild ornamental Iridaceae species. International Journal of Phytoremediation 19 (3): 300-308. doi: 10.1080/15226514.2016.1225282

Cheng LJ, Zhou QX (2014). Phytoremediation of petroleum hydrocarbon contaminated soils using a wild ornamental plant Hylotelephium spectabile (Boreau) H. Ohba. Acta Scientiae Circumstantiae 34: 980-986.

Cheng S, Xiao J, Xiao H, Zhang L, Wu Z (2007). Phytoremediation of triazophos by Canna indica Linn. in a hydroponic system. International Journal of Phytoremediation 9: 453-463. - doi: $10.1080 / 15226510701709531$

Chiesura A (2004). The role of urban parks for the sustainable city. Landscape and Urban Planning 68: 129-138. - doi: 10.1016/j.landurbplan.20 03.08 .003

Chintakovid P, Visoottiviseth S, Khokiattiwong S (2008). Potential of the hybrid marigolds for arsenic phytoremediation and income generation of remediators in Ron Phibun District, Thailand. Chemosphere 70: 1532-1537. - doi: 10.1016/j.che mosphere.2007.08.031

Compernolle T, Van Passel S, Weyens N, Vangronsveld J, Lebbe L, Thewys T (2012). Groundwater remediation and the cost effectiveness of phytoremediation. International Journal of Phytoremediation 14 (9): 861-877. - doi: $10.1080 /$ 15226514.2011.628879

Conway TM, Vander Vecht J (2015). Growing a diverse urban forest: species selection decisions by practitioners planting and supplying trees. Landscape and Urban Planning 138: 1-10. - doi: 10.1016/j.landurbplan.2015.01.007

Cunningham SD, Berti WR (1993). Remediation of contaminated soils with green plants: an overview. In Vitro Cellular and Developmental Biology - Plant 29: 207-212. - doi: 10.1007/BF0263 2036

Dadea C, Russo A, Tagliavini M, Mimmo T, Zerbe $S$ (2017). Tree species as tools for biomonitoring and phytoremediation in urban environments: a review with special regard to heavy metals. Arboriculture and Urban Forestry 43: 155-167.

Desjardins D, Pitre FE, Guidi Nissim W, Labrecque M (2016). Differential uptake of silver, copper and zinc suggests complementary species-specific phytoextraction potential. International Journal of Phytoremediation 18: 598-604. - doi: 10.1080/15226514.2015.1086296

De Miguel E, Iribarren I, Chacon E, Ordonez A, Charlesworth S (2006). Risk-based evaluation of the exposure of children to trace elements in playgrounds in Madrid (Spain). Chemosphere
66: 505-513. - doi: 10.1016/j.chemosphere.2006. 05.065

Di Baccio D, Tognetti R, Sebastiani L, Vitagliano C (2003). Responses of Populus deltoids $\times$ P. nigra (P. $\times$ euramericana) clone I-214 to high zinc concentrations. New Phytologist 159: 443-452. doi: 10.1046/j.1469-8137.2003.00818.x

Doty SL, Freeman JL, Cohu CM, Burken JG, Firrincieli A, Simon A (2017). Enhanced degradation of TCE on a superfund site using endophyte-assisted poplar tree phytoremediation. Environmental Science and Technology 51 (17): 1005010058. - doi: 10.1021/acs.est.7b01504

Ehsan N, Nawaz R, Ahmad S, Khan MM, Hayat J (2016a). Phytoremediation of chromium-contaminated soil by an ornamental plant, vinca (Vinca rosea L.). Journal of Environmental and Agricultural Sciences 7: 29-34. [online] URL: http://www.agropublishers.com/files/JEAS75.P DF

Ehsan N, Nawaz R, Ahmad S, Arshad M, Umair M, Mahmood R (2016b). Use of ornamental plant "Vinca" (Vinca rosea L.) for remediation of lead-contaminated soil. Journal of Biodiversity and Environmental Sciences 8 (3): 46-54. [online] URL: http://www.researchgate.net/pu blication/299229602

Ehsan N, Nawaz R, Ahmad S, Arshad M, Umair M, Sarmad M (2016c). Remediation of heavy metal-contaminated soil by ornamental plant zinnia (Zinnia elegance L.). Asian Journal of Chemistry 28 (6): 1338-1342. - doi: 10.14233/aj chem.2016.19701

Facciotto G, Minotta G, Paris P, Pelleri F (2014). Tree farming, agroforestry and the new green revolution. A necessary alliance. In: Proceedings of the "Second International Congress of Silviculture". Florence (Italy) 26-29 Nov 2014, pp. 7. [online] URL: http://www.researchgate. net/publication/291153366

Ferrini F, Fini A (2011). Sustainable management techniques for trees in the urban areas. Journal of Biodiversity and Ecological Sciences 1: 1-19. [online] URL: http://www.sid.ir/en/journal/View Paper.aspx?ID=202617

Forte J, Mutiti S (2017). Phytoremediation potential of Helianthus annuus and Hydrangea paniculata in copper and lead-contaminated soil. Water, Air and Soil Pollution 228: 77. - doi: 10.1007/ s11270-017-3249-0

Garbisu C, Alkorta I (2001). Phytoextraction: A cost-effective plant-based technology for the removal of metals from the environment. Bioresource Technology 77 (3): 229-236. - doi: 10.1016/Sog60-8524(00)00108-5

Garcia R, Millan E (1998). Assessment of Cd, Pb, and $\mathrm{Zn}$ contamination in roadside soils and grasses from Gipuzkoa (Spain). Chemosphere 37 (8): 1615-1625. - doi: 10.1016/So045-6535(98) 00152-0

Giachetti G, Sebastiani L (2006). Development and chromium uptake in hybrid poplars cultivated on substrate polluted with industrial slags. Advances in Horticultural Science 20: 193198.

Goswami S, Das S (2016). Copper phytoremediation potential of Calendula officinalis $L$. and the role of antioxidant enzymes in metal tolerance. Ecotoxicology and Environmental Safety 126: 211-218. - doi: 10.1016/j.ecoenv.2015.12.030 Guarino C, Paura B, Sciarrillo R (2018). Enhancing phytoextraction of HMs at real scale, by combining Salicaceae trees with microbial consortia. Frontiers in Environmental Science 6: 137. doi: 10.3389/fenvs.2018.00137

Guerra F, Gainza F, Pérez R, Zamudio F (2011). Phytoremediation of heavy metals using poplars (Populus spp.): a glimpse of the plant responses to copper, cadmium and zinc stress. In: "Handbook of Phytoremediation" (Golubev IA ed), Nova Science Publishers, Inc, New York, USA, pp. 387-413.

Guidi W, Kadri H, Labrecque M (2012). Establishment techniques to using willow for phytoremediation on a former oil refinery in southern Quebec: achievements and constraints. Chemistry and Ecology 28 (1): 49-64. - doi: 10.1080/ 02757540.2011 .627857

Guidi W, Pitre FE, Labrecque M (2013). Short-rotation coppice of willows for the production of biomass in Eastern Canada. In: "Biomass Now Sustainable Growth and Use” (Matovic MD ed), InTech Open Science, pp. 421-448. - doi: 10.5772/ 51111

Guidi Nissim W, Pitre FE, Kadri H, Desjardins D, Labrecque M (2014a). Early response of willow to increasing silver concentration exposure. International Journal of Phytoremediation 16: 660-670. - doi: 10.1080/15226514.2013.856840 Guidi Nissim W, Voicu A, Labrecque M (2014b). Willow short-rotation coppice for treatment of polluted groundwater. Ecological Engineering 62: 102-114. - doi: 10.1016/j.ecoleng.2013.10.005 Gülser F, Cig A, Sönmez F (2011). The determination of phytoremediation levels of ornamental plants used in landscape. Journal of International Environmental Application and Science 6: 661-667. [online] URL: http://dergipark.org.tr/ download/issue-full-file/16181

Han Y, Yuan H, Huang S, Guo Z, Xia B, Gu J (2007). Cadmium tolerance and accumulation by two species of Iris. Ecotoxicology 16: $557-$ 563. - doi: 10.1007/s10646-007-0162-0

Hao XZ, Zhou DM, Li DD, Jiang P (2012). Growth, cadmium and zinc accumulation of ornamental sunflower (Helianthus annuus L.) in contaminated soil with different amendments. Pedosphere 22: 631-639. - doi: 10.1016/S1002-0160(12) 60048-4

Henry HF, Burken JG, Maier RM, Newman LA, Rock S, Schnoor JL, Suk WA (2013). Phytotechnologies: preventing exposures, improving public health. International Journal of Phytoremediation 15: 889-899. - doi: 10.1080/15226514. 2012.760521

Houda Z, Bejaou Z, Albouchi A, Gupta DK, Corpas FJ (2016). Comparative study of plant growth of two poplar tree species irrigated with treated wastewater, with particular reference to accumulation of heavy metals ( $\mathrm{Cd}, \mathrm{Pb}, \mathrm{As}$, and $\mathrm{Ni}$ ). Environmental Monitoring and Assessment 188: 99. - doi: 10.1007/s10661-016-5102-0 Huang H, Yu N, Wang L, Gupta D, He Z, Wang K, Zhu Z, Yan X, Li T, Yang Xe (2011). The phytoremediation potential of bioenergy crop Ricinus communis for DDTs and cadmium co-contaminated soil. Bioresource Technology 102 (23): 11034-11038. - doi: 10.1016/j.biortech.2011.09.067 Huinink JTM (1998). Soil quality requirements for use in urban environments. Soil and Tillage Research 47 (1-2): 157-162. - doi: 10.1016/S0167-1987 (98)00087-7 
Huq SMI, Joardar JC, Parvin S (2005). Marigold (Tagetes patula) and ornamental arum (Syngonia sp.) as phytoremediators for arsenic in pot soil. Bangladesh Journal of Botany 34 (2): 6570.

Hussain S, Akram M, Abbas G, Murtaza B, Shahid M, Shah NS, Bibi I, Niazi NK (2017). Arsenic tolerance and phytoremediation potential of $\mathrm{CO}^{-}$ nocarpus erectus L. and Populus deltoides L. International Journal of Phytoremediation 19 (11): 985-991. - doi: 10.1080/15226514.2017.1303815 Jensen JK, Holm PE, Nejrup J, Larsen MB, Borggaard OK (2009). The potential of willow for remediation of heavy metal polluted calcareous urban soils. Environmental Pollution 157: 931-37. - doi: 10.1016/j.envpol.2008.10.024

Khalid S, Shahid M, Niazi NK, Murtaza B, Bibi I, Dumat C (2017). A comparison of technologies for remediation of heavy metal contaminated soils. Journal of Geochemical Exploration 182: 247-268. - doi: 10.1016/j.gexplo.2016.11.021 Khandare RV, Desai SB, Bhujbal SS, Watharkar AD, Biradar SP, Pawar PK, Govindwar SP (2017). Phytoremediation of fluoride with garden ornamentals Nerium oleander, Portulaca oleracea, and Pogonatherum crinitum. Environmental Science and Pollution Research 24 (7): 6833-6839. - doi: 10.1007/s11356-017-8424-8

Khandare NOR, Kabra A, Tamboli D, Govindwar S (2011). The role of Aster amellus Linn. in the degradation of a sulfonated azo dye Remazol Red: a phytoremediation strategy. Chemosphere 82 (8): 1147-1154. - doi: 10.1016/j.chemo sphere.2010.12.073

Killi D, Bussotti F, Gottardini E, Pollastrini $M$, Mori J, Tani C (2018). Photosynthetic and morphological responses of oak species to temperature and $\left[\mathrm{CO}_{2}\right]$ increased to levels predicted for 2050. Urban Forestry and Urban Greening 31: 26-37. - doi: 10.1016/j.ufug.2018.01.012

Landberg T, Greger M (1994). Can heavy metal tolerant clones of Salix be used as vegetation filters on heavy metal contaminated land? In: "Willow Vegetation Filters for Municipal Wastewaters and Sludges. A Biological Purification System" (Aronsson P, Perttu K eds). Swedish University of Agricultural Sciences, Uppsala, pp. 133-144. [online] URL: https://inis.iaea.org /collection/NCLCollectionStore/ Public/27/044/2 7044436.pdf\#page $=123$

Lee S-C, Li X, Shi W, Cheung S-C, Thornton I (2006). Metal contamination in urban, suburban, and country park soils of Hong Kong: a study based on GIS and multivariate statistics. Science of the Total Environment 356 (1-3): 4561. - doi: 10.1016/j.scitotenv.2005.03.024

Leštan D, Luo C-I, Li X- (2008). The use of chelating agents in the remediation of metal-contaminated soils: a review. Environmental Pollution 153: 3-13. - doi: 10.1016/j.envpol.2007.11.015

Lewandowski I, Schmidt U, Londo M, Faaij A (2006). The economic value of the phytoremediation function - assessed by the example of cadmium remediation by willow (Salix ssp.). Agricultural Systems 89 (1): 68-89. - doi: 10.101 6/j.agsy.2005.08.004

Li XX, Zhou ZK (2005). Endemic wild ornamental plants from Northwestern Yunnan, China. Hortscience 40: 1612-1619. - doi: 10.21273/HORTSCI. 40.6.1612

Liu J, Zhou QX, Sun T, Wang XF (2007). Feasibility of applying ornamental plants in contaminated soil remediation. Chinese Journal of Applied Ecology 18: 1617-1623.

Liu J, Schnoor JL (2008). Uptake and translocation of lesser-chlorinated polychlorinated biphenyls (PCBs) in whole hybrid poplar plants after hydroponic exposure. Chemosphere 73: 1608-1616. - doi: 10.1016/j.chemosphere.2008.0 8.009

Liu J, Zhou QX, Sun T, Ma LQ, Wang S (2008). Growth responses of three ornamental plants to $\mathrm{Cd}$ and $\mathrm{Cd}-\mathrm{Pb}$ stress and their metal accumulation characteristics. Journal of Hazardous Materials 151 (1): 261-267. - doi: 10.1016/j.jhazmat. 2007.08.016

Liu Z, He XY, Chen W, Yuan FH, Yan K, Tao DL (2009). Accumulation and tolerance characteristics of cadmium in a potential hyperaccumulator - Lonicera japonica Thunb. Journal of Hazardous Materials 169 (1-3): 170-175. - doi: 10.1016/j.jhazmat.2009.03.090

Liu J, Zhou Q, Wang S (2010). Evaluation of chemical enhancement on phytoremediation effect of Cd-contaminated soils with Calendula officinalis L. International Journal of Phytoremediation 12 (5): 503-515. - doi: 10.1080/1522651 0903353112

Liu R, Jadeja RN, Zhou Q, Liu Z (2012). Treatment and remediation of petroleum-contaminated soils using selective ornamental plants. Environmental Engineering Science 29 (6): 494-501. doi: 10.1089/ees.2010.0490

Liu J, Xin X, Zhou Q (2018). Phytoremediation of contaminated soils using ornamental plants. Environmental Reviews 26 (1): 43-54. - doi: 10.1139/er-2017-0022

Livesley SJ, McPherson GM, Calfapietra C (2016). The urban forest and ecosystem services: impacts on urban water, heat, and pollution cycles at the tree, street, and city Scale. Journal of Environmental Quality 45: 119-124. - doi: 10.2134/jeq2015.11.0567

Ljung K, Selinus O, Otabbong E (2006a). Metals in soils of children's urban environments in the small northern European city of Uppsala. Science of the Total Environment 366 (2-3): 749759. - doi: 10.1016/j.scitotenv.2005.09.073

Ljung K, Selinus O, Otabbong E, Berglund M (2006b). Metal and arsenic distribution in soil particle sizes relevant to soil ingestion by children. Applied Geochemistry 21 (9): 1613-1624. doi: 10.1016/j.apgeochem.2006.05.005

Mahar A, Wang P, Ali A, Awasthi MK, Lahori AH, Wang Q, Li R, Zhang Z (2016). Challenges and opportunities in the phytoremediation of heavy metals contaminated soils: a review. Ecotoxicology and Environmental Safety 126: 111-121. doi: 10.1016/j.ecoenv.2015.12.023

Maila M, Randima P, Cloete TE (2005). Multispecies and monoculture rhizoremediation of polycyclic aromatic hydrocarbons (PAHs) from the soil. International Journal of Phytoremediation 7 (2): 87-98. - doi: 10.1080/16226510590950397 Marmiroli M, Pietrini F, Maestri E, Zacchini M, Marmiroli N, Massacci A (2011). Growth, physiological and molecular traits in Salicaceae trees investigated for phytoremediation of heavy metals and organics. Tree Physiology 31: 13191334. - doi: 10.1093/treephys/tprogo

McGrath SP, Zhao FJ (2003). Phytoextraction of metals and metalloids from contaminated soils.
Current Opinion in Biotechnology 14: 277-282. doi: 10.1016/S0958-1669(03)00060-0

Meers E, Vandecasteele B, Ruttens A, Vangronsveld J, Tack FMG (2007). Potential of five willow species (Salix spp.) for phytoextraction of heavy metals. Environmental and Experimental Botany 60 (1): 57-68. - doi: 10.1016/j.envexpbot. 2006.06.008

Meng L, Qiao M, Arp H (2011). Phytoremediation efficiency of a PAH-contaminated industrial soil using ryegrass, white clover, and celery as mono- and mixed cultures. Journal of Soils and Sediments 11 (3): 482-490. - doi: 10.1007/s11368010-0319-y

Miao Q, Yan JH (2013). Comparison of three ornamental plants for phytoextraction potential of chromium removal from tannery sludge. Journal of Material Cycles and Waste Management 15 (1): 98-105. - doi: 10.1007/s10163-0120095-4

Miller RW, Hauer RJ, Werner LP (2015). Urban forestry: planning and managing urban greenspaces ( $3^{\text {rd }}$ edn). Waveland Press, Long Grove, IL, USA, pp. 56o. [online] URL: http://books. google.com/books?id=Vdl_CQAAQBAJ

Mleczek M, Rutkowski P, Rissmann I, Kaczmarek Z, Golinski P, Szentner K, Strazynska K, Stachowiak A (2010). Biomass productivity and phytoremediation potential of Salix alba and Salix viminalis. Biomass and Bioenergy 34 (9): 1410-1418. - doi: 10.1016/j.biombioe.2010.04.012 Mohammadzadeh A, Tavakoli M, Chaichi MR, Motesharezadeh B (2014). Effects of nickel and PGPBs on growth indices and phytoremediation capability of sunflower (Helianthus annuus L.). Archives of Agronomy and Soil Science 60 (12): 1765-1778. - doi: 10.1080/03650340.2014.89 8839

Motesharezadeh B, Kamalpoor S, Alikhani HA, Zarei M, Azimi S (2017). Investigating the effects of plant growth promoting bacteria and Glomus mosseae on cadmium phytoremediation by Eucalyptus camaldulensis L. Pollution 3: 575-588. - doi: 10.22059/poll.2017.62774

Mukherjee A, Agrawal M (2018). Use of GLM approach to assess the responses of tropical trees to urban air pollution in relation to leaf functional traits and tree characteristics. Ecotoxicology and Environmental Safety 152: 4254. - doi: 10.1016/j.ecoenv.2018.01.038

Nanda Kumar PBA, Dushenkov V, Motto H, Raskin I (1995). Phytoextraction: the use of plants to remove heavy metals from soils. Environmental Science and Technology 29 (5): 12321238. - doi: 10.1021/es00005a014

Nikolić M, Stevović S (2015). Family Asteraceae as a sustainable planning tool in phytoremediation and its relevance in urban areas. Urban Forestry and Urban Greening 14: 782-789. - doi: 10.1016/j.ufug.2015.08.002

Pajević S, Borišev M, Nikolić N, Arsenov D, Orlović S, Zupunski M (2016). Phytoextraction of heavy metals by fast-growing trees: a review. In: "Phytoremediation Management of Environmental Contaminants" (Ansari AA, Gill SS, Gill R, Lanza GR, Newman L eds). Springer International Publishing, Cham, Switzerland, pp. 29-64. - doi: 10.1007/978-3-319-40148-5_2 Pathak V, Tripathi BD, Mishra VK (2011). Evaluation of anticipated performance index of some tree species for green belt development to mit- 
igate traffic generated noise. Urban Forestry and Urban Greening 10 (1): 61-66. - doi: 10.1016/j. ufug.2010.06.008

Pulford ID, Watson C (2003). Phytoremediation of heavy metal-contaminated land by trees - a review. Environment International 29: 529-540. - doi: 10.1016/S0160-4120(02)00152-6

Ramana S, Biswas AK, Singh AB, Ajay Naveen Kumar P, Ahirwar NK, Behera S, Subba Rao A (2012). Phytoremediation of cadmium contaminated soils by tuberose. Indian Journal of Plant Physiology 17 (1): 61-64. [online] URL: http:// www.researchgate.net/publication/236258876 Ramana S, Biswas AK, Singh AB, Ahirwar NK (2013). Evaluation of phytoremediation ability of some floricultural plant species. Plant Physiology Reports 18 (2): 187-190. - doi: 10.1007/s40 502-013-0029-8

Ramana S, Biswas AK, Singh AB, Ahirwar NK, Rao AS (2015). Tolerance of ornamental succulent plant crown of thorns (Euphorbia milli) to chromium and its remediation. International Journal of Phytoremediation 17 (4): 363-368. doi: 10.1080/15226514.2013.862203

Reed ST, Ayala-Silva T, Dunn CB, Gordon GG, Meerow A (2013). Screening ornamentals for their potential as accumulator plants. Journal of Agricultural Science 5 (10): 20-27. - doi: 10.5539/jas.v5n10p20

Ribeiro De Souza S, López De Andrade A, Anjos De Souza L, Schiavinato MA (2012). Lead tolerance and phytoremediation potential of Brazilian leguminous tree species at the seedling stage. Journal of Environmental Management 110: 299-307. - doi: 10.1016/j.jenvman.2012.06. 015

Roloff A, Korn S, Gillner S (2009). The climatespecies matrix to select tree species for urban habitats considering climate change. Urban Forest and Urban Greening 8 (4): 295-308. - doi: 10.1016/j.ufug.2009.08.002

Rosselli W, Keller C, Boschi K (2003). Phytoextraction capacity of trees growing on metal contaminated soil. Plant Soil 256 (2): 265-272. doi: 10.1023/A:1026100707797

Salt DE, Blaylock M, Nanda Kumar PBA, Dushenkov V, Ensley BD, Chet I, Raskin I (1995). Phytoremediation: a novel strategy for the removal of toxic metals from the environment using plants. Nature Biotechnology 13: 468-474. - doi: 10.1038/nbt0595-468

Saxena G, Purchase D, Mulla SI, Saratale GD, Saxena $G$ (2019). Phytoremediation of heavy metalcontaminated sites: eco-environmental concerns, field studies, sustainability issues, and future prospects. Reviews of Environmental Contamination and Toxicology 249: 71-131. - doi: 10.1007/398_2019_24

Scheyer JM (2000). Estimating dietary risk from soils in urban gardens. In: "Proceedings of the First International Conference on Soils of Urban, Industrial, Traffic and Mining Areas" (Burghardt W, Dornauf C eds). Essen (Germany) 12-18 July 2000, vol. 2, pp. 479-484.

Schleu U, Wu Q, Blume H-P (1998). Variability of soils in urban and periurban areas in Northern Germany. Catena 33 (3-4): 255-270. - doi: 10.1016 /S0341-8162(98)00070-8

Scholz T, Hof A, Schmitt T (2018). Cooling effects and regulating ecosystem services provided by urban trees novel analysis approaches using ur- ban tree cadastre data. Sustainability 10 (3): 118. - doi: 10.3390/su10020001

Shah K, Pathak L (2019). Transgenic energy plants for phytoremediation of toxic metals and metalloids. In: "Transgenic Plant Technology for Remediation of Toxic Metals and Metalloids" (Narasimha M, Prasad V eds). Academic Press, CA, USA, pp. 319-340. - doi: 10.1016/B9780-12-814389-6.00015-8

Shimp JF, Tracy JC, Davis LC, Lee E, Huang W, Erickson LE, Schnoor JL (1993). Beneficial effects of plants in the remediation of soil and groundwater contaminated with organic materials. Critical Reviews in Environmental Science and Technology 23: 41-77. - doi: 10.1080/1064338930 9388441

Signes-Pastor AJ, Munera-Picazo S, Burlo F, Cano-Lamadrid M, Carbonell-Barrachina AA (2015). Phytoremediation assessment of Gomphrena globosa and Zinnia elegans grown in arsenic-contaminated hydroponic conditions as a safe and feasible alternative to be applied in arsenic-contaminated soils of the Bengal Delta. Environmental and Monitoring Assessment 187: 387. - doi: 10.1007/s10661-015-4618-z

Sleegers F (2010). Phytoremediation as green infrastructure and a landscape of experiences In: Proceedings of the "Annual International Conference on Soils, Sediments, Water and Energy", vol. 15, Article 13. [online] URL: http:// scholarworks.umass.edu/soilsproceedings/vol1 5/iss $1 / 13$

Solanki P, Narayan M, Rabha AK, Srivastava RK (2018). Assessment of cadmium scavenging potential of Canna indica L. Bulletin of Environmental Contamination and Toxicology 101 (4): 446-450. - doi: 10.1007/s00128-018-2416-3

Stevović S, Mikovilović VS, Calić-Dragosavac D (2010). Environmental study of heavy metals influence on soil and Tansy (Tanacetum vulgare L.). African Journal of Biotechnology 9: 23922400. [online] URL: http://www.ajol.info/index. php/ajb/article/view/78473

Subhashini V, Swamy AVVS (2013). Phytoremediation of $\mathrm{Pb}$ and $\mathrm{Ni}$ contaminated soils using Catharanthus roseus (L.). Universal Journal of Environmental Research and Technology 3 (4): 465-472. [online] URL: http://www.environ mentaljournal.org/3-4/ujert-3-4-7.pdf

Subhashini V, Swamy AVVS (2014). Phytoremediation of metal ( $\mathrm{Pb}, \mathrm{Ni}, \mathrm{Zn}, \mathrm{Cd}$ and $\mathrm{Cr}$ ) contaminated soils using Canna indica. Current World Environment 9 (3): 780-784. - doi: 10.12944/ CWE.9.3.26

Sun Y, Zhou Q (2016). Uptake and translocation of benzo[a]pyrene (B[a]P) in two ornamental plants and dissipation in soil. Ecotoxicology and Environment Safety 124: 74-81. - doi: 10.1016/j. ecoenv.2015.09.037

Tao JM, Wang YB, Dai J (2011). Accumulation and tolerance of zinc in ornamental plant Chlorophytum comosum. Applied Mechanics and Materials 66- 68: 524-27. - doi: 10.4028/www.scien tific.net/AMM.66-68.524

Tauqeer HM, Ali S, Rizwan M, Ali Q, Saeed R, Iftikhar U, Ahmad R, Farid M, Abbasi GH (2016). Phytoremediation of heavy metals by Alternanthera bettzickiana: growth and physiological response. Ecotoxicology and Environmental Safety 126: 138-146. - doi: 10.1016/j.ecoenv.2015.12. 031
Terzaghi E, Vergani L, Mapelli F, Borin S (2019). Rhizoremediation of weathered PCBs in a heavily contaminated agricultural soil: results of a biostimulation trial in semi field conditions. Science of the Total Environment 686: 484-496. doi: 10.1016/j.scitotenv.2019.05.458

Tiller KG (1992). Urban soil contamination in Australia. Australian Journal of Soil Research 30: 937-957. - doi: 10.1071/SR9920937

Turgut C, Pepe MK, Cutright TJ (2004). The effect of EDTA and citric acid on phytoremediation of $\mathrm{Cd}, \mathrm{Cr}$, and $\mathrm{Ni}$ from soil using Helianthus annuus. Environmental Pollution 131 (1): 147-154. - doi: 10.1016/j.envpol.2004.01.017

Turner AP, Dickinson NM, Lepp NW (1991). Indices of metal tolerance in trees. Water, Air, and Soil Pollution 57-58 (1): 617-625. - doi: 10.1007/BFo0282925

Vassilev A, Schwitzguebel J-P, Thewys T, Lelie D, Vangronsveld J (2004). The use of plants for remediation of metal-contaminated soils. The Scientific World Journal 4: 9-34. - doi: 10.1100/tsw. 2004.2

Vyslouzilová M, Tlustoš P, Száková J (2003). Cadmium and zinc phytoextraction potential of seven clones of Salix spp. planted on heavy metal contaminated soils. Plant Soil and Environment 49 (12): 542-547. - doi: 10.17221/4191PSE

Waranusantigul P, Kruatrachue M, Pokethitiyook $\mathrm{P}$, Auesukaree C (2008). Evaluation of $\mathrm{Pb}$ phytoremediation potential in Buddleja asiatica and B. paniculata. Water Air and Soil Pollution 193: 79-90. - doi: 10.1007/s11270-008-9669-0

Watharkar AD, Jadhav JP (2014). Detoxification and decolorization of a simulated textile dye mixture by phytoremediation using Petunia grandiflora and Gailardia grandiflora: a plantplant consortial strategy. Ecotoxicology and Environmental Safety 103: 1-8. - doi: 10.1016/j. ecoenv.2014.01.033

Wan X, Lei M, Chen T (2016). Cost-benefit calculation of phytoremediation technology for heavy-metal contaminated soil. Science of the Total Environment 563- 564: 796-802. - doi: 10.1016/j.scitotenv.2015.12.080

Wang XF, Zhou QX (2005). Ecotoxicological effects of cadmium on three ornamental plants. Chemosphere 60 (1): 16-21. - doi: 10.1016/j.chem osphere.2004.12.031

Wang Y, Yan A, Dai J, Wang NN, Wu D (2012). ACcumulation and tolerance characteristics of cadmium in Chlorophytum comosum: a popular ornamental plant and potential $\mathrm{Cd}$ hyperaccumulator. Environmental Monitoring and Assessment 184: 929-937. - doi: 10.1007/s10661-0112010-1

Wei SQ, Pan SW (2010). Phytoremediation for soils contaminated by phenanthrene and pyrene with multiple plant species. Journal of Soils and Sediments 10 (5): 886-894. - doi: 10.1007/s11368-010-0216-4

Wu FZ, Yang WQ, Zhang J, Zhou LQ (2011). Growth responses and metal accumulation in an ornamental plant (Osmanthus fragrans var. thunbergii) submitted to different Cd levels. International Scholarly Research Network, vol. 2011, Art. ID 738138. - doi: 10.5402/2011/738138 Yongpisanphop J, Babel S, Kruatrachue $M$, Pokethitiyook P (2017). Hydroponic screening of fast-growing tree species for lead phytore- 
mediation potential. Bulletin of Environment Contamination and Toxicology 99 (4): 518-523. doi: 10.1007/s00128-017-2157-8

Zacchini M, Pietrini F, Scarascia Mugnozza G, Iori V, Pietrosanti L, Massacci A (2009). Metal tolerance, accumulation and translocation in poplar and willow clones treated with cadmium in hydroponics. Water Air and Soil Pollution: 23-34. doi: 10.1007/s11270-008-9788-7

Zayad AM, Terry N (2003). Chromium in the environment: factors affecting biological remedia- tion. Plant and Soil 249 (1): 139. - doi: 10.1023/A: 1022504826342

Zeng P, Guo Z, Cao X, Xiao X, Liu Y, Shi L (2018).

Phytostabilization potential of ornamental plants grown in soil contaminated with cadmium. International Journal of Phytoremediation 20 (4): 311-320. - doi: 10.1080/15226514.20 17.1381939

Zeng P, Guo G, Xiao X, Peng C, Feng W (2019). Phytoextraction potential of Pteris vittata $\mathrm{L}$. COplanted with woody species for $\mathrm{As}, \mathrm{Cd}, \mathrm{Pb}$ and
$\mathrm{Zn}$ in contaminated soil. Science of the Total Environment 650 (1): 594-603. - doi: 10.1016/j.sci totenv.2018.09.055

Zhang CP, Qui S, Zhao J, Li XJ, Quan YB (2010). Phytoremediation properties of three ornamental plants for cadmium absorption in soils. Journal of Guangxi Agricultural Science 41 (10): 1101-1103. [online] URL: http://www.cabdirect. org/cabdirect/abstract/20113030693 